\title{
Dendritic Calcium Signaling in ON and OFF Mouse Retinal Ganglion Cells
}

\author{
David J. Margolis, ${ }^{1}$ Andrew J. Gartland, ${ }^{1}$ Thomas Euler, ${ }^{2}$ and Peter B. Detwiler ${ }^{1}$ \\ ${ }^{1}$ Department of Physiology and Biophysics and Program in Neurobiology and Behavior, University of Washington, Seattle, Washington 98195, and \\ ${ }^{2}$ Department of Biomedical Optics, Max Planck Institute for Medical Research, D-69120 Heidelberg, Germany
}

Retinal ganglion cells (RGCs) are the output cells of the retina; they convert synaptic input into spike output that carries visual information to the brain. Synaptic inputs are received, integrated and communicated to the spike initiation zone of the axon by dendrites whose properties are poorly understood. Here simultaneous patch-clamp recording and 2-photon $\mathrm{Ca}^{2+}$ imaging are used to study voltage- and light-evoked $\mathrm{Ca}^{2+}$ signals in the dendrites of identified types of mouse RGCs from parallel ON and OFF pathways, which encode the onset and offset of light, respectively. The results show pathway-specific differences in voltage-dependent $\mathrm{Ca}^{2+}$ signaling. While both $\mathrm{ON}$ and OFF cells express high-voltage-activated (HVA) $\mathrm{Ca}^{2+}$ channels, only OFF RGCs also express low-voltage-activated (LVA) $\mathrm{Ca}^{2+}$ channels. LVA Ca ${ }^{2+}$ channels in OFF cells are deinactivated by hyperpolarization from the resting potential and give rise to rebound excited $\mathrm{Ca}^{2+}$ spikes at the termination of a step of either hyperpolarizing current or light. This suggests that the differential expression of voltage-gated $\mathrm{Ca}^{2+}$ channels in ON and OFF RGC dendrites contributes to differences in the way the two cell types process visual stimuli.

\section{Introduction}

The mammalian retina is a neural image processor designed to detected and encode information about distinctive visual features, the most basic of which are changes in luminance. This begins at the first synapse in the retina where photoreceptor signals are transmitted to bipolar cell types that differ by depolarizing in response to either an increase or decrease in light level (Werblin and Dowling, 1969). In this way the light-driven signal from the photoreceptors is divided into two separate main pathways that reach the CNS via output cells, retinal ganglion cells (RGCs), that are excited by either a light increment or decrement and are known as ON and OFF type RGCs, respectively (Nelson and Kolb, 2004). One group of ON and OFF RGCs can be recognized morphologically on the basis of having large somas and distinct dendritic stratification profiles. These cells are referred to as $\alpha$ RGCs (Peichl, 1991) in recognition of their large somas. In mouse retina they include one type of $\alpha$ ON cell and two types of $\alpha$ OFF cells; OFF transient (OFF-T) and OFF sustained (OFF-S), based on whether they respond to light offset with a transient or

\footnotetext{
Received Nov. 14, 2009; revised March 26, 2010; accepted April 3, 2010.

Funding was provided by National Institutes of Health Grants EY02048 (P.B.D.), GM07108 (D.J.M.), Human Frontiers Science Program Grant RGP-0067 (A.J.G.), and the Max Planck Society (T.E.). This work would not have been possible without the expertise, generous material support, and critical acumen of Winfried Denk, who designed and essentially built the custom-made 2-photon microscope that our experiments depend on. We are also grateful to Fred Rieke and Bill Spain for many enlightening discussions and comments on an earlier version of the manuscript and to Patrick Theer and Paul Newman for technical assistance.

Correspondence should be addressed to either of the following: Peter B. Detwiler at the above address, E-mail: detwiler@u.washington.edu; or David J. Margolis, Department of Neurophysiology, Brain Research Institute, University of Zurich, Winterthurerstrasse 190, CH-8057 Zurich, Switzerland, E-mail: margolis@hifo.uzh.ch.

T. Euler's present address: Center for Integrative Neuroscience (CIN), University of Tübingen, Röntgenweg 11, D-72076 Tübingen, Germany.

DOI:10.1523/JNEUROSCI.5694-09.2010

Copyright $\odot 2010$ the authors $\quad 0270-6474 / 10 / 307127-12 \$ 15.00 / 0$
}

sustained burst of spikes (Pang et al., 2003; Margolis and Detwiler, 2007; van Wyk et al., 2009).

The differences between ON and OFF RGCs are due to differences in the organization and dynamics of the synaptic inputs they receive (Werblin and Dowling, 1969; Awatramani and Slaughter, 2000; Roska et al., 2006), as well as to differences in their inherent electrophysiological properties that shape the cell's electrical response to light. The intrinsic differences between $\mathrm{ON}$ and OFF cells include differences in their voltage-gated $\mathrm{Ca}^{2+}$ channels (VGCCs) (Margolis and Detwiler, 2007; Margolis et al., 2008). Since the dendrites of these cells are the sites of synaptic input from presynaptic bipolar and amacrine cells, differences in dendritic Ca signaling could contribute to the differences in the way the cells process visual information. To examine this in more detail simultaneous 2-photon $\mathrm{Ca}^{2+}$ imaging and whole-cell electrical recording was used to study the properties of the voltageand light-evoked dendritic $\mathrm{Ca}^{2+}$ signals in ON and OFF $\alpha$ RGCs in the intact isolated mouse retina.

Our results show that light-evoked dendritic $\mathrm{Ca}^{2+}$ signals are dominated by VGCCs in both ON and OFF cells, with different complements in each cell type. ON cells express only highvoltage-activated $\mathrm{Ca}^{2+}$ channels while OFF cells express highand low-voltage-activated $\mathrm{Ca}^{2+}$ channels, with the relative expression of the latter appearing to increase with dendritic distance from the soma. In OFF cells, low-voltage-activated $\mathrm{Ca}^{2+}$ channels can be activated at light offset giving rise to rebound excitation and low-threshold dendritic $\mathrm{Ca}^{2+}$ spikes. These findings suggest that voltage-gated $\mathrm{Ca}^{2+}$ channels differentially contribute to the visual function of RGCs from parallel ON and OFF retinal pathways.

\section{Materials and Methods}

Animals. All experiments were done in accordance with local and national guidelines for animal care. Subjects were 4- to 8-week-old male or 
A

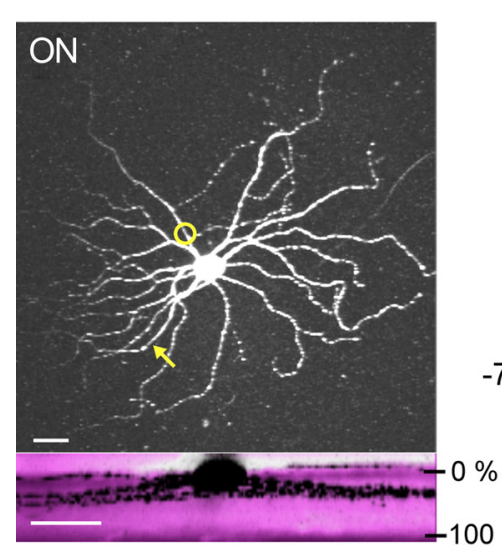

B
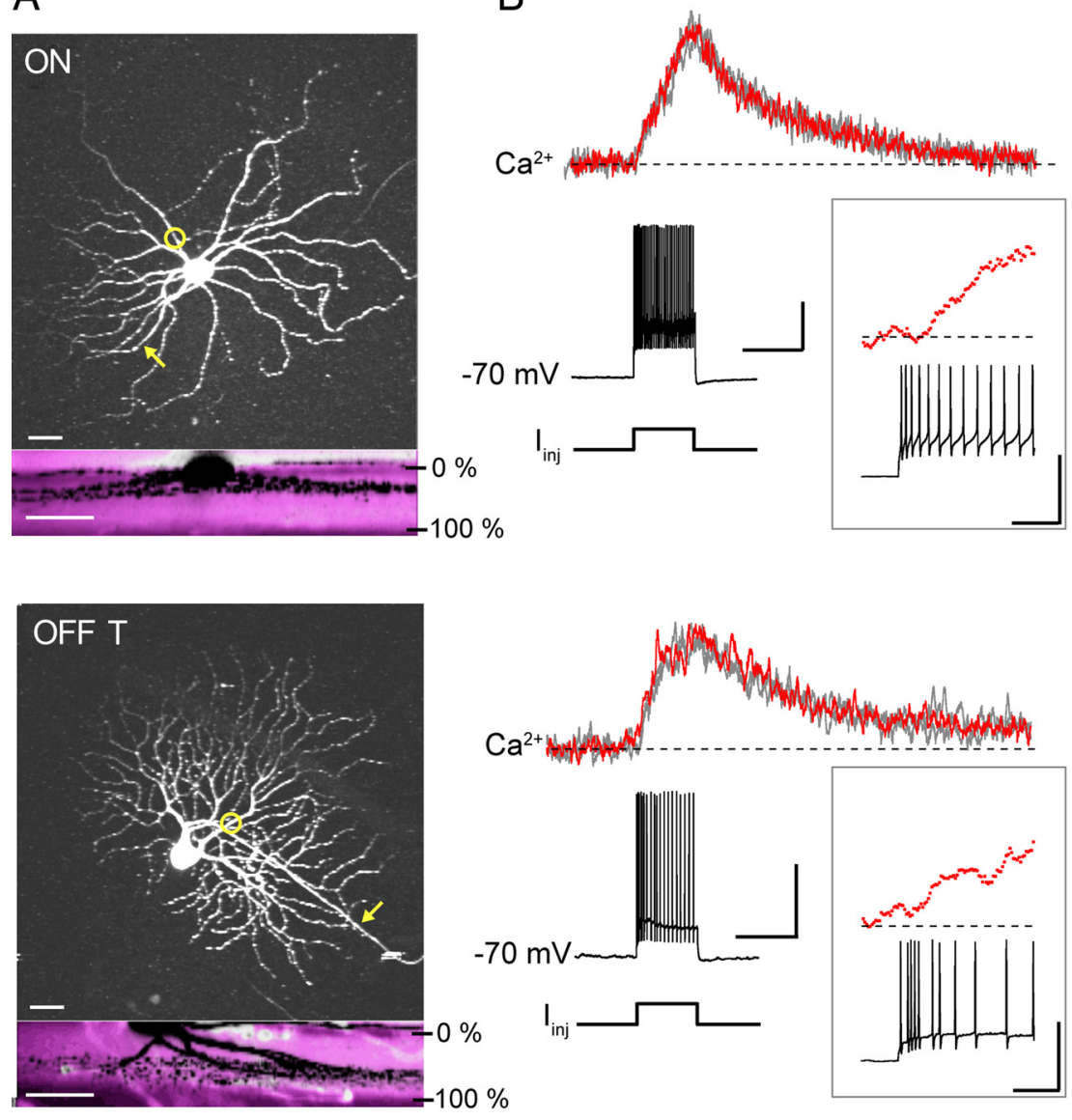

$\mathrm{D}$

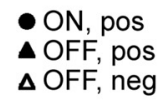
$\Delta$ OFF, pos
$\Delta$ OFF, neg

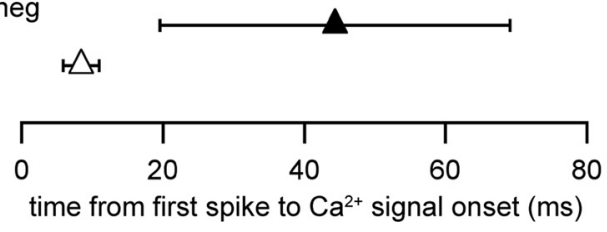

C
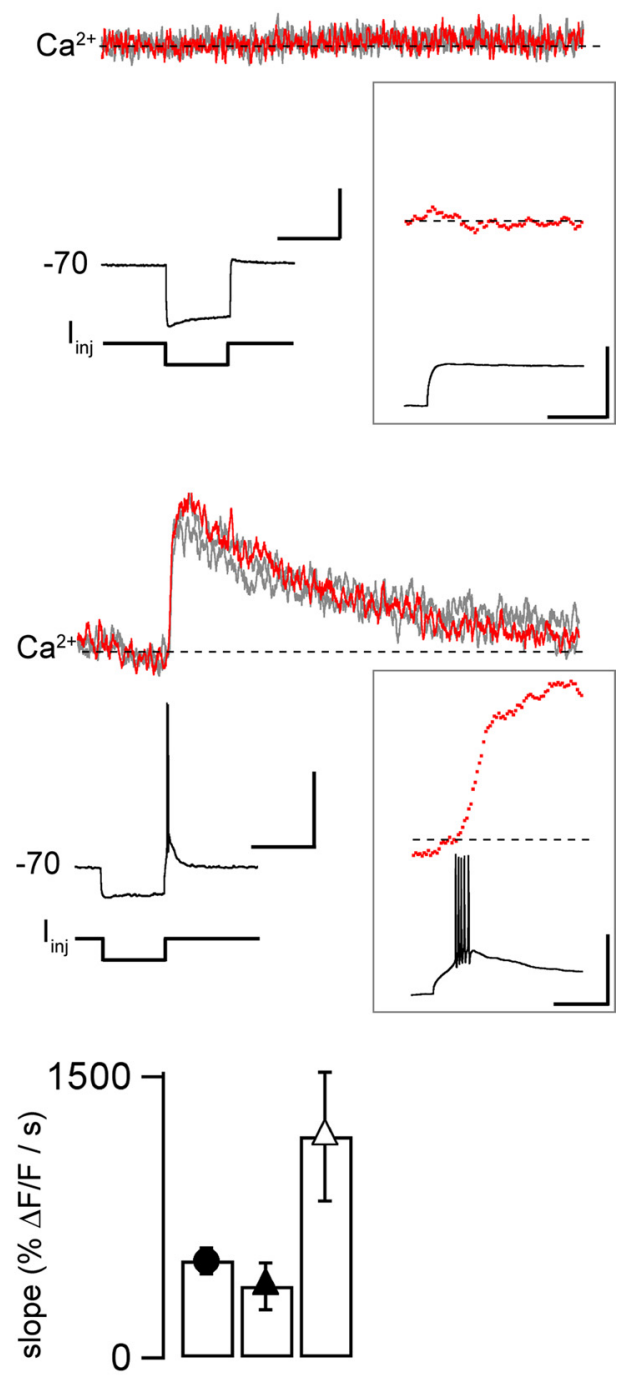

Figure 1. Dendritic $\mathrm{Ca}^{2+}$ signals evoked by depolarization and rebound excitation. A, Morphology of ON (top) and OFF-T (bottom) RGCs in isolated intact mouse retina. Two-photonz-projections (top) and side-projections (bottom) following patch-clamp recordings with $140 \mu \mathrm{M}$ OGB-1 included in the patch pipette. Side-projections show overlay of simultaneously acquired green fluorescence from filled cells (black) and red fluorescence from bath-applied sulforhodamine (magenta), respectively. IPL borders indicated as $0 \%$ and $100 \%$. Circles show linescan positions in $\boldsymbol{B}$ and $\boldsymbol{C}$; arrows indicate axons. Scale bars, $25 \mu \mathrm{m} . B_{1} \mathrm{Ca}^{2+}$ signals during spiking responses to depolarizing current injection in ON (top) and OFF-T (bottom) RGCs ( + $300 \mathrm{pA} \mathrm{for} 0 \mathrm{~N}$ cell; $+200 \mathrm{pA}$ for $0 \mathrm{FF}-\mathrm{T}$ cell). Each plot shows three individual responses. Red traces highlight an individual response and are shown in insets on faster time scale. Scale bars (main panel) for $0 \mathrm{~N}$ cell are $20 \mathrm{mV}, 50 \% \Delta F / F$, $0.5 \mathrm{~s}, 0 \mathrm{FF}$ cell $30 \mathrm{mV}, 45 \% \Delta F / F, 0.5 \mathrm{~s}$. Scale bars in insets are $40 \mathrm{mV}, 40 \% \Delta F / F, 0.5$ sfor both $0 \mathrm{~N}$ and $0 \mathrm{FF}$ cell. C, $\mathrm{Ca}^{2+}$ signals in response to hyperpolarizing current injection in the same cells $(-260$ $\mathrm{pA}$ for $0 \mathrm{~N}$ cell; $-200 \mathrm{pA}$ for OFF-T cell). Note rebound burst fired by $0 \mathrm{FF}-\mathrm{T}$ cell at termination of negative current step. $\mathrm{Ca}^{2+}$ signals measured at the same dendritic locations as in $\boldsymbol{B}$. Colors and insets as in $\boldsymbol{B}$. Maximum spike frequencies for OFF-T cell in $\boldsymbol{B}$ and $\boldsymbol{C}$ were similar ( $\sim 270 \mathrm{~Hz}$ ). $\boldsymbol{D}$, Delay time between (a signal onset (see Materials and Methods) and occurrence of first AP was $38.5 \pm 12.7$ $\mathrm{ms}$ and $44.3 \pm 24.7 \mathrm{~ms}$ for depolarizing stimuli in ON and OFF cell respectively. Delay time for rebound excitation in OFF cell was $8.4 \pm 2.5 \mathrm{~ms}$. Bar graph (right hand panel) showing rising slopes of $\mathrm{Ca}^{2+}$ signals evoked by depolarizing steps and rebound excitation in the two cell types. Symbols are mean $\pm \mathrm{SEM}$ ( $n=5 \mathrm{ON}, 40 \mathrm{FF}-\mathrm{T}$ cells). Recordings made in the presence of synaptic blockers mixture (in $\mu \mathrm{m}: 50 \mathrm{~L}-\mathrm{APB}, 20$ CNQX, 50 APV, 1 strychnine, 50 picrotoxin).

female wild-type (WT) C57BL/6 mice, housed in temperature-regulated facilities on a 12/12 h light/dark cycle with free access to food and water. In a subset of experiments, transgenic mice from the Thyl-YFP-H line [Tg(Thy1-YFPH)2Jrs, Jackson Laboratory] were used to target certain morphological types of cells. Results from these animals were indistinguishable from WT and were pooled. For dark-adapted experiments, mice were housed in a light-tight chamber for $1.5-12 \mathrm{~h}$ before experiments, and all subsequent procedures were performed using infrared (IR) illumination and image converters. For semi dark-adapted experiments, mice were dark-adapted as above then dissections were performed under light-adapted conditions; this state of adaptation helped to minimize effects of 2-photon laser stimulation of photoreceptors (Euler et al., 2009). For experiments using synaptic blockers, rendering the retina insensitive to light, mice were not dark-adapted and dissections and experiments were done under light-adapted conditions.

Tissue preparation. Mice were killed by cervical dislocation. Eyes were removed into room temperature Ames medium (Sigma) equilibrated with carbogen $\left(95 \% \mathrm{CO}_{2} / 5 \% \mathrm{O}_{2}\right)$, hemisected, and the cornea and lens removed. The resulting eyecup was cut into 2-4 pieces, and the retina was isolated by gently teasing it from the pigment epithelium. Extra pieces/eyecups were stored in room temperature Ames until needed. The vitreous was removed from the retina with forceps before mounting it flat, photoreceptor-side down, onto Anodisc filter paper (Whatman) and into the recording chamber. The custom chamber was mounted onto a 
A
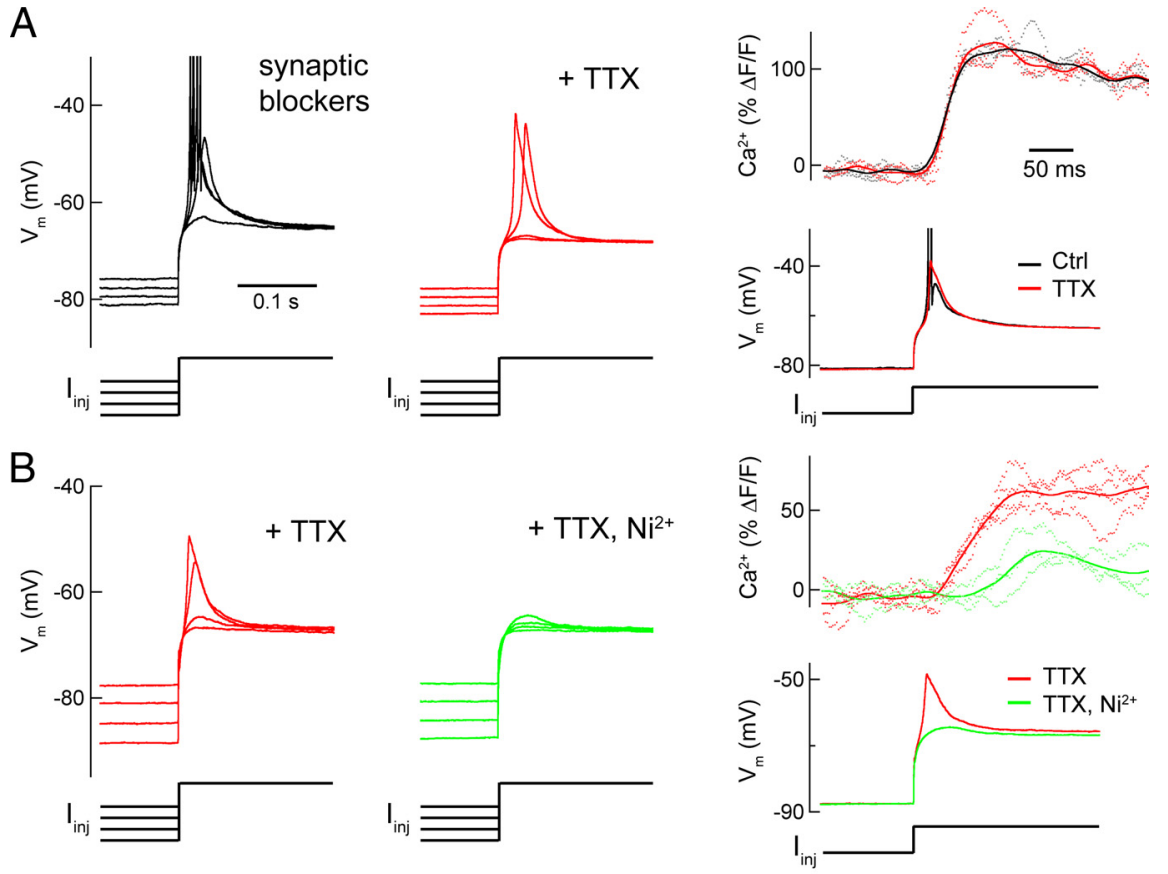

C
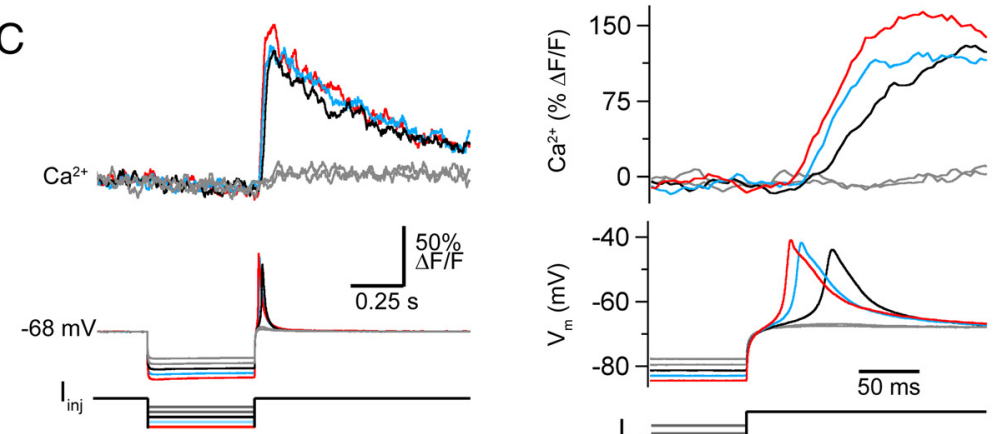

D

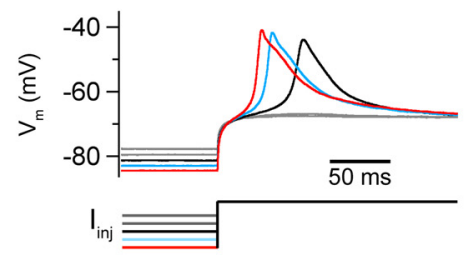

$E$

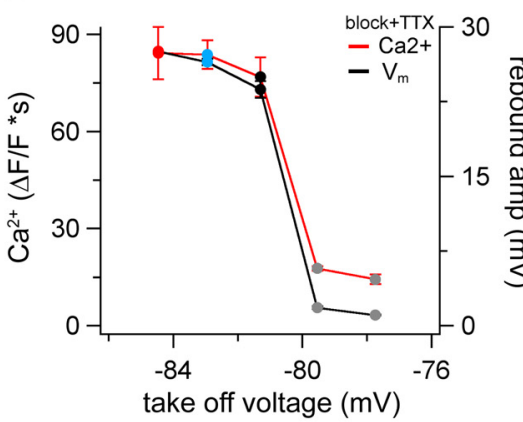

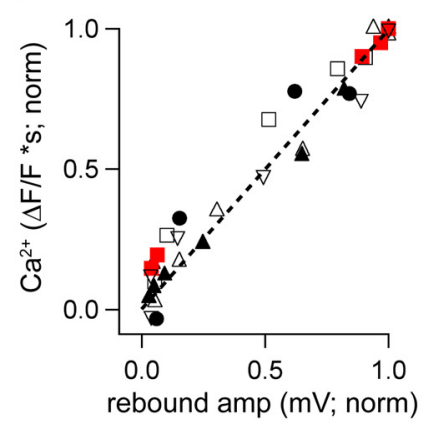

Figure 2. TTX-insensitive, $\mathrm{Ni}^{2+}$-sensitive $\mathrm{Ca}^{2+}$ spike triggered by rebound excitation in $\mathrm{OFF}$ cells. $A$, Rebound responses to a series of hyperpolarizing current injections in an 0FF-T cell in the presence of synaptic blockers (left) before and after addition of 0.1 $\mu \mathrm{M}$ TTX (middle). Overlaid traces show responses to same family of currents ( $-400,-480,-560,-640 \mathrm{pA} ; 0.5 \mathrm{~s}$ duration). APs are truncated. Right panels compare $\mathrm{Ca}^{2+}$ signals from proximal dendrite (top; dotted lines individual responses, solid line averages) to the same hyperpolarizing stimulus before (black) and after addition of TTX (red). $\boldsymbol{B}$, Rebound responses in a different OFF-T cell in the presence of synaptic blockers with $0.1 \mu \mathrm{M} \mathrm{TTX} \mathrm{(red;} \mathrm{left)} \mathrm{and} \mathrm{after} \mathrm{addition} \mathrm{of} 100 \mu \mathrm{m} \mathrm{NiCl}$ ( $^{2+}{ }^{2+}$; green traces). Responses to families of injected currents are overlaid $(-160,-220,-280,-340 \mathrm{pA} ; 0.5 \mathrm{~s}$ duration). Right panels compare proximal $\mathrm{Ca}^{2+}$ signals and rebound responses in synaptic blockers with TTX before (red) and after application of $\mathrm{Ni}^{2+}$ (green). Synaptic blockers mixture same as Figure 1. C, Rebound-evoked $\mathrm{Ca}^{2+}$ signals in synaptic blockers and TTX to a series of hyperpolarizing current steps ( -360 to $-200 \mathrm{pA}, 40 \mathrm{pA}$ increment; means of 4$)$. The close temporal correspondence of voltage and $\mathrm{Ca}^{2+}$ signals for the three strongest responses is shown (right panel). $\boldsymbol{D}$, Amplitude of rebound voltage and $\mathrm{Ca}^{2+}$ signal versus take-off voltage, which is the voltage at the end of the hyperpolarizing current step. $V_{m}$ and $\mathrm{Ca}^{2+}$ both show a sudden increase at an apparent threshold around $-80 \mathrm{mV}$. Values are mean \pm SD of responses to 4 sweeps for cell in $C$. $E$, Area of $\mathrm{Ca}^{2+}$ signals versus peak of voltage responses (both normalized to maximum) for $60 \mathrm{FF}-\mathrm{T}$ cells. Data from cell in $\boldsymbol{C}$ and $\boldsymbol{D}$ shown in red.

2-photon microscope (see below) and superfused with warmed $\left(30-34^{\circ} \mathrm{C}\right)$ Ames at a rate of $4-9 \mathrm{ml} / \mathrm{min}$.

Electrical recordings. The flat-mount retina was viewed on a video monitor using infrared illumination and a CCD camera. Cells in the ganglion cell layer with large diameter (18-25 $\mu \mathrm{m})$ somas were targeted for patch-clamp recordings in the flat-mount retina. A patch pipette was used to expose cells of interest by micro-dissecting the internal limiting membrane. Current- and voltage-clamp recordings were made with 3-7 $M \Omega$ glass electrodes. Signals were amplified using either Axopatch 200B, Axoclamp 2B, or Multiclamp 700B amplifiers (Molecular Devices). Series resistance was minimized and compensated $(>\sim 70 \%)$ with the amplifier circuitry [bridge mode of Axoclamp, fast current-clamp (CC) mode of Axopatch, and automatically with Multiclamp]. Recordings were discarded if series resistance was $>20 \mathrm{M} \Omega$. Input resistances of cells were $\sim 50-100 \mathrm{M} \Omega$, as in earlier work (Margolis and Detwiler, 2007). The internal solution was (in mM): $120 \mathrm{~K}$-gluconate, $5 \mathrm{NaCl}, 5 \mathrm{KCl}, 5$ HEPES, $1 \mathrm{MgCl}_{2}, 1$ adenosine 5'-triphosphate, and 0.1 guanosine $5^{\prime}$-triphosphate, adjusted to pH 7.4 with $\mathrm{KOH}$, plus either 125-140 $\mu \mathrm{M}$ Oregon Green BAPTA-1 (OGB-1) or $250 \mu \mathrm{m}$ Fluo-5F (Invitrogen). In experiments with Fluo5F, $100 \mu \mathrm{m}$ Alexa-594 was also included for ratiometric measurements (see Optical recording, below). Current and voltage stimuli were generated and data acquired through an ITC-16 interface (Instra-Tech) using software written by Fred Rieke (University of Washington, Seattle, WA), or with an ITC-18 interface using software written by A.J.G.

In some experiments (see Figs. 1-5) a mixture of synaptic blockers was used to isolate cells from synaptic input. The standard blockers mixture contained $(\mu \mathrm{M}) 50$ L-APB, 20 CNQX, $50 \mathrm{APV}, 1$ strychnine, 50 picrotoxin. In additional experiments $(\mu \mathrm{M}) 0.1 \mathrm{TTX}$ and/or $100 \mathrm{NiCl}_{2}$ were also used. Chemicals were purchased from Sigma-Aldrich or Tocris Bioscience. In current-clamp recordings in the presence of synaptic blockers, negative DC holding current was required to match the voltage of OFF cells to that of ON cells, because OFF cells show spontaneous firing in the absence of synaptic input, as previously described (Margolis and Detwiler, 2007).

Cell identification. Retinal ganglion cells (RGCs) were identified as ON, OFF-transient or OFF-sustained based on physiological and morphological criteria, as in previous work (Margolis and Detwiler, 2007). These cells have large diameter somas $(18-25 \mu \mathrm{m})$, characteristic responses to light, reliable levels of dendritic stratification within the inner plexiform layer (IPL), and distinguishing intrinsic electrophysiological properties (Pang et al., 2003; Murphy and Rieke, 2006; Margolis and Detwiler, 2007). In the presence of synaptic blockers, cells were identified using the latter two criteria (Margolis and Detwiler, 2007). OFF-T cells can additionally be identified on the basis of their large amplitude low-voltage-activated $\mathrm{Ca}^{2+}$ currents (see Results). 
Optical recordings. Fluorescence measurements were made using a custom built 2-photon laser-scanning microscope (Denk et al., 1990; Euler et al., 2009) designed around Sutter micromanipulators (Sutter Instruments) and controlled by CfNT software (written by Ray Stepnoski, Bell Labs, Murray Hill, NJ; and Michael Müller, Max Planck Institute for Medical Research, Heidelberg, Germany). Fluorescence excitation was provided by a pumped infrared laser (Mira; Coherent Inc.) at $905-930 \mathrm{~nm}$, and collected by two photomultiplier tubes (Hamamatsu). Custom bandpass filters (Chroma Technology) directed green $(535 \pm 50 \mathrm{~nm})$ and red $(622 \pm 36$ $\mathrm{nm}$ ) light to separate PMTs. The green channel was used for $\mathrm{Ca}^{2+}$ indicator fluorescence, and the red channel was used for either bathapplied Sulforhodamine-101 (used as a counterstain) or intracellularly introduced Alexa-594.

Changes in intracellular $\mathrm{Ca}^{2+}$ were most commonly measured using a single wavelength $\mathrm{Ca}^{2+}$-dependent fluorescent indicator (OGB1). After background subtraction, the change in fluorescence $(\Delta \mathrm{F})$ was divided by the initial fluorescence $\left(F_{0}\right)$ to obtain a measure $\left(\Delta F / F_{0}\right)$ that is proportional to the change in $\mathrm{Ca}^{2+}$. The results obtained with OGB-1 were verified in a subset of experiments using a combination of calcium-sensitive (Fluo-5F) and calciuminsensitive (Alexa-594) fluorophores to make ratiometric $\mathrm{Ca}^{2+}$ measurements. In these studies the change in $\mathrm{Ca}^{2+}$-sensitive fluorescence $(\Delta G)$ was divided by the $\mathrm{Ca}^{2+}$ insensitive fluorescence $(R)$ to provide a $\mathrm{Ca}^{2+}$ measurement $(\Delta G / R)$ that is not sensitive to local differences in physical factors that can influence fluorescence measurements (Yasuda et al., 2004).

Proximal imaging sites were $\sim 10-30 \mu \mathrm{m}$ from the soma along the primary dendrite; distal sites were as close to the dendritic tips as possible (on average $140 \mu \mathrm{m}$ from soma); intermediate sites were at arbitrary locations in between. Line scans were acquired at $500 \mathrm{~Hz}$.

Light stimuli. Light stimuli were either a yellow LED whose size (50-500 $\mu \mathrm{m}$ at the recording chamber) was controlled by an aperture and focused onto the retina through a substage condenser, or a spot generated by an LCoS (liquid crystal on silicon) display and projected through the objective (Euler et al., 2009). A wavelength of $578 \pm 10 \mathrm{~nm}$ was chosen to be outside the range of green and red fluorescent indicators. Light intensity was in the high mesopic/low photopic range $(\sim 100-200$ photons $/ \mu \mathrm{m}^{2} / \mathrm{s}$ ).

Data analysis. Electrophysiological data were analyzed in Igor Pro (Wavemetrics). Images were analyzed in Igor Pro and ImageJ (http:// rsb.info.nih.gov/ij/). $\mathrm{Ca}^{2+}$ signals were expressed as the percentage change from baseline, after background subtraction $(\% \Delta F / F) . \mathrm{Ca}^{2+}$ signal onset was defined as the time to reach $3 \times$ the $\mathrm{SD}$ of the baseline signal. For Figure 1, this was measured relative to the time of the first stimulated action potential. For Figure 4, onset was measured relative to the start time of the voltage ramp command. In both cases baseline SD was measured over 100-300 ms before stimulation and was determined independently for each cell on a single sweep basis. Peak $\mathrm{Ca}^{2+}$ signals were measured as the average over a small time window centered on the

A

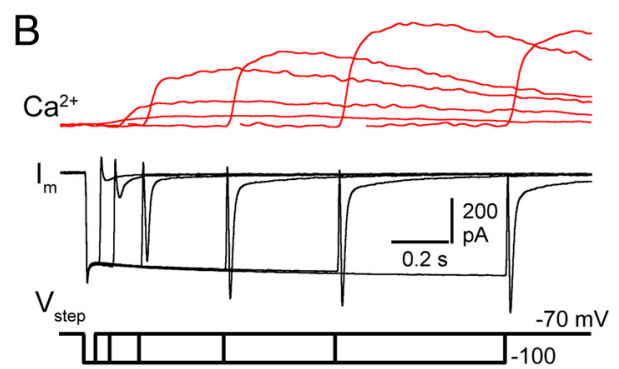

OFF T
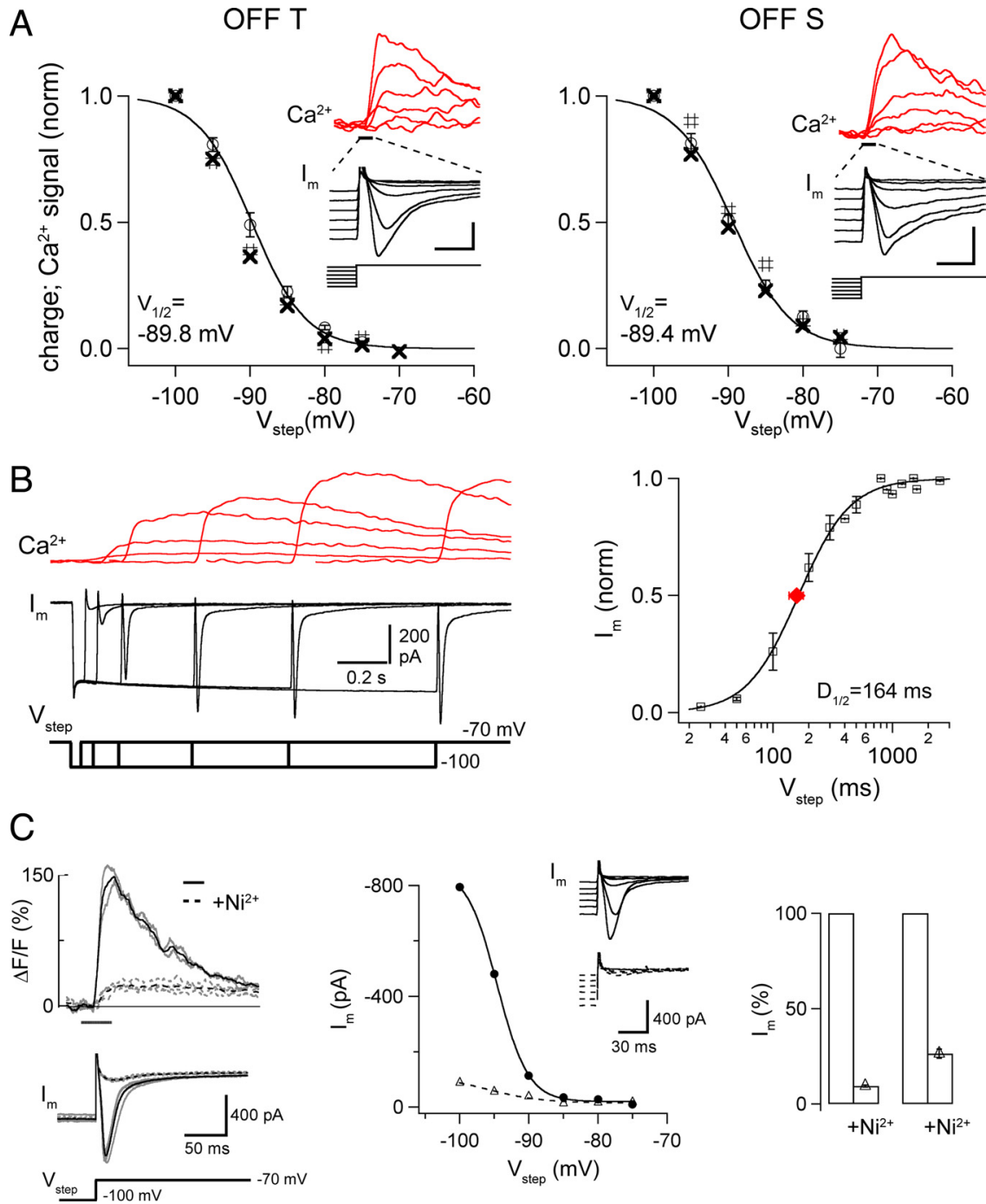

Figure 3. Properties of rebound-evoked inward currents and $\mathrm{Ca}^{2+}$ signals in OFF cells. $A$, Graphs plot (open circles) normalized area of the inward current (charge) evoked by voltage steps to $-70 \mathrm{mV}$ from different amplitude prepotentials; group data (OFF-T, $n=7$, left; OFF-S, $n=5$ cells). Separate symbols show area of current (\#) and $\mathrm{Ca}^{2+}$ signal (X) from individual cells in insets; scale bars, $200 \mathrm{pA} / 30 \% \Delta \mathrm{F} / \mathrm{F}, 0.2 \mathrm{~s}(0 \mathrm{FF}-\mathrm{T}) ; 200 \mathrm{pA} / 80 \% \Delta \mathrm{F} / \mathrm{F}, 0.2 \mathrm{~s}$ (OFF-S). Note the close correspondence between currents and $\mathrm{Ca}^{2+}$ signals. $V_{\text {half }}$ values are from Boltzmann fits to average data (see Materials and Methods) with $k$ (slope factor): $3.60 \pm 0.310 \mathrm{FF}-\mathrm{T}$; $3.83 \pm 0.40$ OFF-S. B , Simultaneously recorded whole-cell currents and proximal $\mathrm{Ca}^{2+}$ signals from an 0FF-T cell following a voltage step from $V_{\text {hold }}=-70$ to $-100 \mathrm{mV}$ for varying lengths of time. $\mathrm{Ca}^{2+}$ indicator in this experiment was $250 \mu \mathrm{m}$ Fluo-5F. Right side panel shows normalized current versus step duration for 3 OFF-T cells. Current increased with duration of deinactivating step. The average time for half-deinactivation $\left(D_{1 / 2}\right.$, red symbol) from fit of Hill equation (see Materials and Methods) was $164 \pm$ $21 \mathrm{~ms} . \mathrm{C}_{,} \mathrm{Ca}^{2+}$ signals (top, left side) and whole-cell currents (below) in an OFF-T cell in response to voltage step from - 100 to $-70 \mathrm{mV}$ before (solid line) and after (dotted line) application of $100 \mu \mathrm{M} \mathrm{NiCl}$. Means of 2-4 sweeps (black) show that Ni ${ }^{2+}$ reduced currents and $\mathrm{Ca}^{2+}$ signals similarly. Middle, Peak current versus $V_{\text {hold }}$ in control (solid line) and $\mathrm{Ni}^{2+}$ (dotted line) for the same 0FF-T cell. Insets show individual current sweeps in response to voltage steps from six negative prepotentials (between -75 and $-100 \mathrm{mV}$ ) to $-70 \mathrm{mV}$. Right, Bar graph showing the mean $\mathrm{Ni}^{2+}$-induced reduction of peak (left, $91 \pm 1 \%$ ) and area (right, $73 \pm 2 \%$ ) of rebound-evoked inward current in response to a voltage step from -100 to $-70 \mathrm{mV}$. All recordings made in the presence of synaptic blockers mixture (see Materials and Methods) and $0.1 \mu \mathrm{M}$ TTX.

absolute peak, or the peak of smoothed traces; both methods gave similar results. Area $\left(\Delta F / F^{*} \mathrm{~s}\right)$ was measured as the integrated unsmoothed signal. Slope was measured from a linear fit to the rising phase of the smoothed trace (mean slope), because the peak value of differentiated sweeps (maximum slope) was less robust with inherently noisy optical signals.

A Boltzmann equation was used to fit inactivation curves (see Fig. $3 \mathrm{~A}$ ) (Crunelli et al., 1989; Lee et al., 2003). $I(V)=I_{\max } /(1+\exp [(V-$ $\left.\left.V_{\text {half }}\right) / k\right]$ ), where $I$ is peak current at each test voltage, $I_{\max }$ is peak current at $-70 \mathrm{mV}, V$ is test voltage, $V_{\text {half }}$ is midpoint of fit, and $k$ is voltage for an $e$-fold change around $V_{\text {half }}$ (i.e., slope factor). A Hill equation was used to fit deinactivation curves (see Fig. $3 B): I(V)=1 /\left(1+\left[V_{\text {half }} / V\right] \exp k\right)$. 


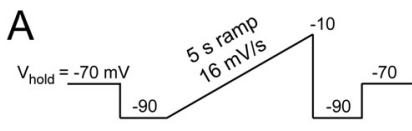

B

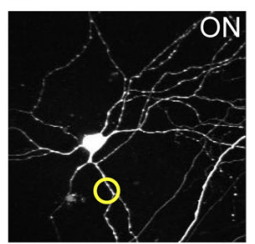

C
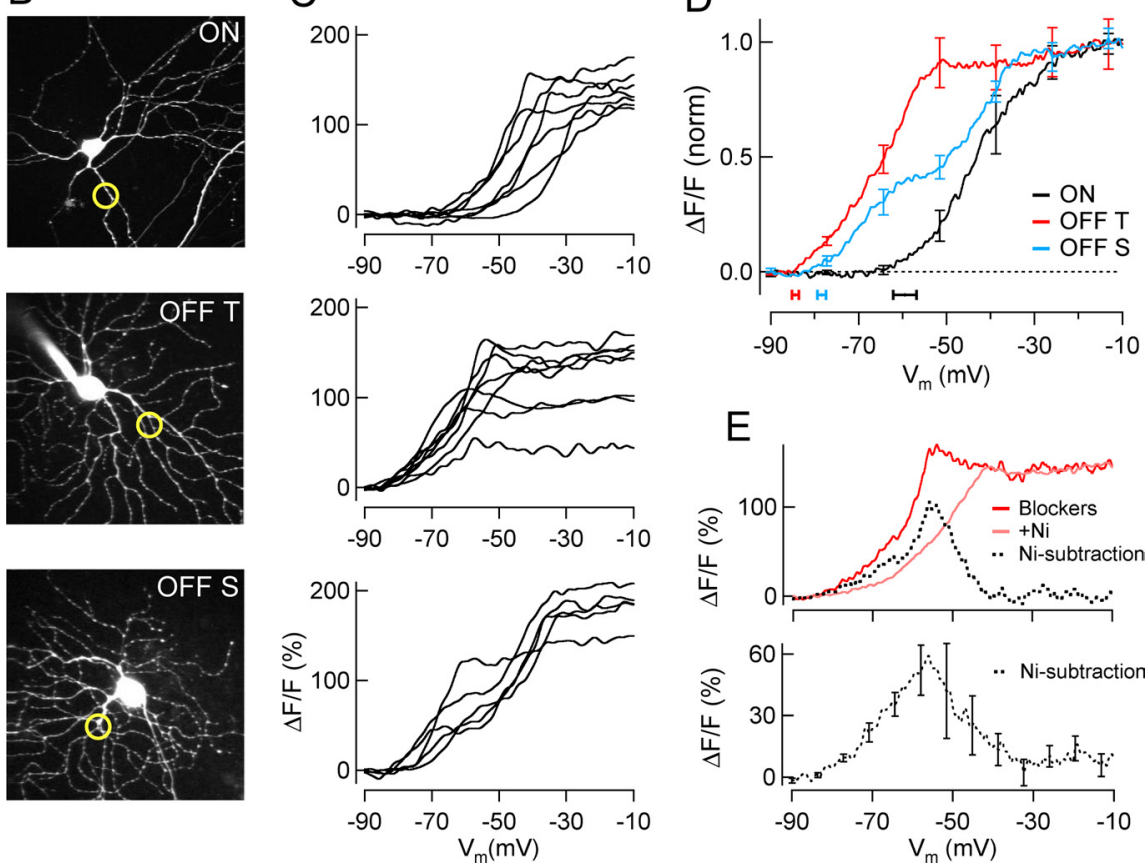

Figure 4. Calcium signals evoked by slow voltage ramps. $\boldsymbol{A}$, Voltage-clamp ramp command. $\boldsymbol{B}$, Two-photon fluorescence images ( $z$-stack projections) of example ON, OFF-T and OFF-S RGCs with optical recording sites indicated by circles. $C, \mathrm{Ca}^{2+}$ dependent fluorescence change recorded from the three cell types in B in response to voltage ramp depicted in $A$. Each traces is mean signal ( $2-4$ sweeps) from a different cell. $\boldsymbol{D}$, Group means ( $n=70 \mathrm{~N}, 80 \mathrm{FF}-\mathrm{T}, 50 \mathrm{FF}-\mathrm{S})$. Activation voltage ( \pm SEM) of Ca ${ }^{2+}$ signal shown below by horizontal bars $(0 \mathrm{~N},-59.5 \pm 2.7 \mathrm{mV}, n=7 ; 0 \mathrm{FF}-\mathrm{T},-84.4 \pm 0.8 \mathrm{mV}, n=8 ; 0 \mathrm{FF}-\mathrm{S},-78.4 \pm 1.0 \mathrm{mV}$ $n=5) . \boldsymbol{E}, \mathrm{Ni}^{2+}$-subtraction experiment in a representative OFF-T cell (top) showing the low-voltage-activated $\mathrm{Ca}^{2+}$ signal obtained by subtracting ramp response before and after $\mathrm{Ni}^{2+}$ exposure. The mean voltage dependence of the $\mathrm{Ni}^{2+}$-isolated $\mathrm{Ca}^{2+}$ signal in 3 OFF-T cells (bottom). Recordings made in the presence of synaptic blockers mixture (see Materials and Methods) and 0.1 $\mu \mathrm{M}$ TTX.

Charge of low-voltage-activated currents was measured as the integrated current in the $200 \mathrm{~ms}$ following current steps from negative voltages to $-70 \mathrm{mV}$, excluding the first $4 \mathrm{~ms}$ due to capacitive transients.

\section{Results}

\section{Voltage-evoked dendritic $\mathrm{Ca}^{2+}$ signals}

In both ON and OFF RGCs, a step of depolarizing current from $\sim-70 \mathrm{mV}$ generated a train of action potentials (APs) and an increase in dendritic $\mathrm{Ca}^{2+}$ that had similar amplitude and kinetics in the two cell types (Fig. $1 B$ ). In OFF but not ON RGCs a burst of APs and an increase in dendritic $\mathrm{Ca}^{2+}$ was also evoked by rebound excitation (Fig. $1 C$ ) when membrane voltage overshot the resting potential at the termination of a step of hyperpolarizing current. As reported previously (Margolis et al., 2008), the $\mathrm{Ca}^{2+}$ increase $(\% \Delta F / F)$ per AP was $\sim 10$-fold larger for rebound-evoked than for depolarization-evoked responses, despite the fact that rebound bursts contained $\sim 4$-fold fewer spikes at a similar maximum rate. Comparing the dynamics of $\mathrm{Ca}^{2+}$ increases evoked by depolarizing current injection and those evoked by rebound excitation revealed that reboundevoked $\mathrm{Ca}^{2+}$ increases had on average $\sim 4$-fold faster onset (time to $3^{\star}$ SD baseline; see Materials and Methods), rose with $\sim 4$-fold steeper slope (Fig. $1 D)$ and reached $\sim 2.5$-fold (2.5 \pm 0.7 -fold, $p=0.014, n=5$ OFF T cells) larger peak amplitude. These features indicate recruitment of additional $\mathrm{Ca}^{2+}$-dependent mechanisms by hyperpolarization.

\section{High- and low-voltage-activated} $\mathrm{Ca}^{2+}$ entry

Tetrodotoxin (TTX, $0.1 \mu \mathrm{M}$ ) blocks the train of APs evoked by depolarizing current injection in ON and OFF RGCs, as well as the brief burst of spikes triggered by rebound excitation in OFF cells. The absence of the large fast TTX-sensitive spikes during rebound responses in OFF cells exposed an underlying depolarization that was up to $25 \mathrm{mV}$ in amplitude and appeared to have a distinct activation threshold from hyperpolarized potentials (Fig. $2 \mathrm{~A}$ ). The rebound-evoked $\mathrm{Ca}^{2+}$ increase was not affected by TTX (Fig. $2 \mathrm{~A}$, right), but was strongly reduced by 100 $\mu \mathrm{M} \mathrm{Ni}^{2+}$ (Fig. 2B).

The relationship between the underlying rebound depolarization and the $\mathrm{Ca}^{2+}$ signal was studied by returning to the resting potential from different amplitude hyperpolarizing prepotentials in the presence of TTX. The termination of small hyperpolarizing steps produced "subthreshold" rebound depolarization and caused little to no $\mathrm{Ca}^{2+}$ increase (Fig. 2C). The potential change at the end of larger amplitude hyperpolarizing steps evoked rebound depolarizations that appeared to exceed a threshold to trigger "all-ornone" low-threshold spikes that were accompanied by large amplitude dendritic $\mathrm{Ca}^{2+}$ increases (Fig. 2C,D). The low threshold events appear to be dendritic $\mathrm{Ca}^{2+}$ spikes on the basis of their association with a robust dendritic $\mathrm{Ca}^{2+}$ increase and their persistence in the presence of TTX. The rebound $\mathrm{Ca}^{2+}$ increase occurred with a latency that decreased as the amplitude of the hyperpolarizing prepotential was increased, and was coincident with the onset of the rebound depolarization (Fig. 2C, right). The close correspondence between rebound voltage and $\mathrm{Ca}^{2+}$ signal amplitude is shown for an example cell in Figure $2 D$ and for a group of OFF-T cells in Figure $2 E$. These results suggest that rebound depolarization is generated by low-voltage-activated $\mathrm{Ca}^{2+}$ channels that are deinactivated by hyperpolarization making them available for activation when the membrane potential is depolarized upon returning to the resting potential. This is the mechanism for rebound depolarization in many other cell types (Llinás, 1988; Llinás and Mühlethaler, 1988; Huguenard, 1996; Aizenman and Linden, 1999; Molineux et al., 2006) including RGCs in other species (Lee et al., 2003; Mitra and Miller, 2007). Steps of hyperpolarizing current produced maintained voltage changes that had little to no delayed depolarization or "sag" (Margolis and Detwiler, 2007), as would be expected to occur if hyperpolarization activated a nonselective cation current $\left(I_{\mathrm{h}}\right)$. For this reason the possibility that such a current contributes to rebound-evoked excitation in OFF RGCs was not investigated further.

The properties of the current that gives rise to rebound depolarization in OFF RGCs as well as the recruitment of the $\mathrm{Ca}^{2+}$ 
channels that mediate it and the accompanying dendritic $\mathrm{Ca}^{2+}$ increase were studied in voltage clamp. These experiments were done in the presence of TTX and synaptic blockers by stepping back to the resting potential $(-70 \mathrm{mV})$ from hyperpolarizing prepotentials of different amplitudes and durations (Fig. 3). The positive voltage change at the termination of a hyperpolarizing step evoked a transient inward current and a fast increase in dendritic $\mathrm{Ca}^{2+}$; both increased with the amount the cell was hyperpolarized during the prepotential, reaching a maximum for steps from -100 to $-70 \mathrm{mV}$ (Fig. $3 A$ ). OFF RGCs did not tolerate steps from more hyperpolarized prepotentials. The inward current and the $\mathrm{Ca}^{2+}$ signal were half-maximally activated by the termination of steps that held the cell at $\sim-90 \mathrm{mV}$. The amplitude of both signals increased with the duration of the hyperpolarizing prepotential (Fig. 3B). A step from -100 to $-70 \mathrm{mV}$ that lasted $\sim 160 \mathrm{~ms}$ caused half-maximal activation of the current. The reboundevoked current and $\mathrm{Ca}^{2+}$ responses were greatly $(70-90 \%)$ reduced by $\mathrm{Ni}^{2+}$ (Fig. $3 C$ ) and had similar voltage and time dependences in OFF-T and OFF-S cells, despite differences in their amplitude and kinetics in the two OFF cell types (supplemental Fig. 1 , available at www.jneurosci.org as supplemental material).

The voltage dependence of dendritic $\mathrm{Ca}^{2+}$ signals over a larger voltage range was compared in ON and OFF RGCs by recording the $\mathrm{Ca}^{2+}$-dependent fluorescence signal as membrane potential was ramped ( $16 \mathrm{mV} / \mathrm{s}, 5 \mathrm{~s}$ ramp) from -90 to $-10 \mathrm{mV}$ in voltage clamp (Fig. 4). The induction of $\mathrm{Ca}^{2+}$ entry in OFF cells began at low voltages and continued throughout the voltage excursion of the ramp (Fig. 4C). On average the $\mathrm{Ca}^{2+}$ increase turned on at voltages in the vicinity of $-80 \mathrm{mV}$ in OFF cells (threshold activation $-84.4 \pm 0.8 \mathrm{mV}$ OFF-T $n=8$, and $-78.4 \pm 1.0 \mathrm{mV}$ OFF-S $n=5)$ and $\sim-60$ $\mathrm{mV}$ in ON cells $(-59.5 \pm 2.7 \mathrm{mV}, n=7)$ (Fig. 4D). Similar results were obtained using positive voltage steps (data not shown). Thus the predominant pathway for $\mathrm{Ca}^{2+}$ entry in ON and OFF RGCs is different; OFF cells have an activation threshold more negative than the resting potential (LVA Ca ${ }^{2+}$ entry) and ON cells have an activation threshold more positive than the resting potential, i.e., high-voltage-activated (HVA) $\mathrm{Ca}^{2+}$ entry. The LVA $\mathrm{Ca}^{2+}$ signal present in OFF but not ON cells was isolated by subtracting the $\mathrm{Ca}^{2+}$-voltage ramp curves obtained before and after $\mathrm{Ni}^{2+}$ treatment from each other (Fig. $4 E$ ). Many OFF cells, especially OFF-S cells, showed a prominent "double hump" profile suggesting separate low and high-voltage activation; in
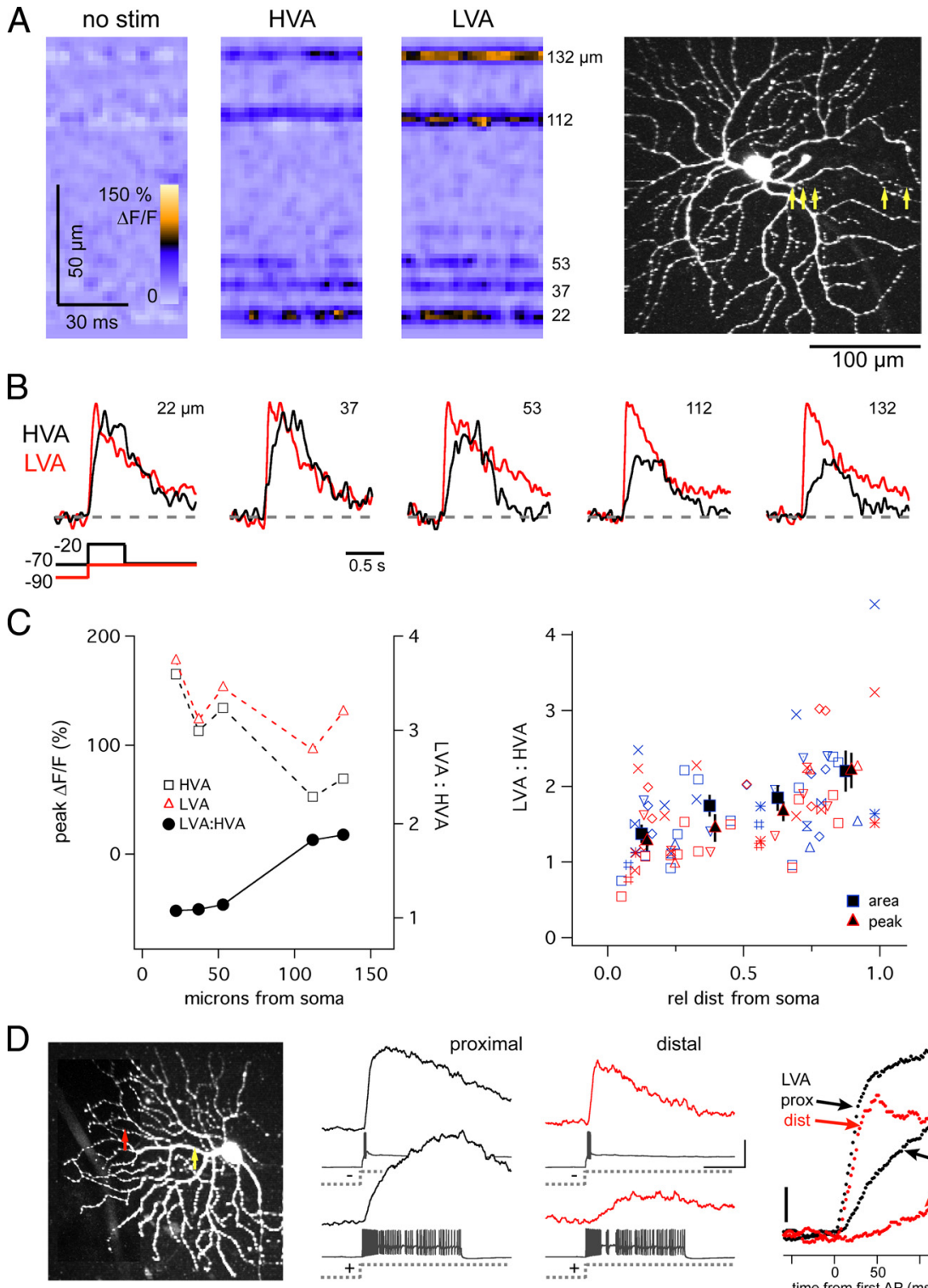

Figure 5. Spatial properties of $\mathrm{HVA}$ and $\mathrm{LVACa}^{2+}$ signals. $A$, Line scan measurement of $\mathrm{Ca}^{2+}$ signals from 5 dendritic locations in an OFF-T cell in response to HVA ( $0.5 \mathrm{~s}$ voltage-clamp step from -70 to $-20 \mathrm{mV})$ and LVA $(0.5 \mathrm{~s}$ from -100 to $-70 \mathrm{mV})$ favoring stimuli. Numbers at right indicate distance of each recording site from soma. Scan locations shown with yellow arrows on 2-photon z-projection. $B, \mathrm{Ca}^{2+}$ signals from each of 5 regions, normalized to peak $\mathrm{LVACa}^{2+}$ response, showing that HVA signals decrease more steeply with distance than LVA signals. $\boldsymbol{C}$, Amplitude of $\mathrm{Ca}^{2+}$ signals from data in $\boldsymbol{B}$ (dotted lines) and ratio of peak LVA:HVA signals (solid line). HVA and LVA signals both decrease with distance, but LVA:HVA increases. The LVA:HVA ratio versus relative distance from soma for 9 OFF-T cells is plotted in C, right. Blue is area, red is peak, and like symbols represent individual cells. Relative distance is normalized to the total dendritic length of each cell. Mean proximal site $=22 \pm 3$; mean distal site $=$ $140 \pm 13 ;$ range $=8-201 \mu \mathrm{m}$. Both area and peak measurements indicated. Solid symbols indicate mean ( \pm SEM) for each 0.25 segment bin. $\mathbf{D}$, Comparison of proximal and distal $\mathrm{Ca}^{2+}$ signals during spiking and rebound responses in current-clamp recording. Injected current $\left( \pm 350 \mathrm{pA}\right.$ ) produced $\sim 13 \mathrm{mV}$ depolarization (spike subtracted), and $-24 \mathrm{mV}$ hyperpolarization from $V_{\text {hold }}=-70 \mathrm{mV}$. Scanning positions indicated on the 2-photon z-projection by circles; proximal and distal recording sites were, respectively, 31 and $94 \mu \mathrm{m}$ from soma. Right, $\mathrm{Ca}^{2+}$ signals superimposed and aligned to time of first AP showing rising phase differences at proximal and distal recording sites for LVA and HVA Ca ${ }^{2+}$ signals. Recordings made in the presence of synaptic blockers mixture (see Materials and Methods) with (A-C) and without (D) $0.1 \mu \mathrm{m}$ TTX.

OFF-T cells, the high-voltage hump may have been masked by stronger LVA $\mathrm{Ca}^{2+}$ entry.

\section{Spatial properties of voltage-evoked $\mathrm{Ca}^{2+}$ signals}

The spatial distribution of HVA and LVA Ca channels was explored under voltage-clamp conditions using stimuli that favored either HVA $\mathrm{Ca}^{2+}$ entry (a depolarizing step from 
ON

A
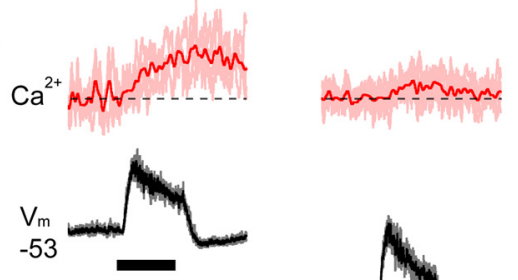

$\mid \begin{aligned} & 40 \% \Delta \mathrm{F} / \mathrm{F} \\ & 12 \mathrm{mV}\end{aligned}$

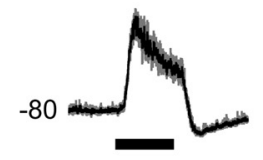

B
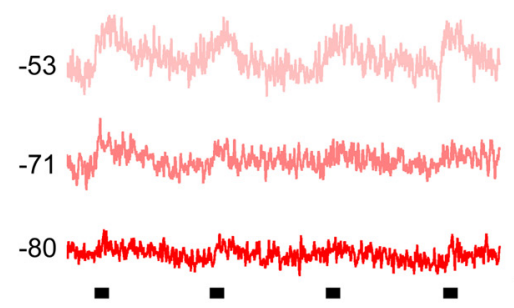

C
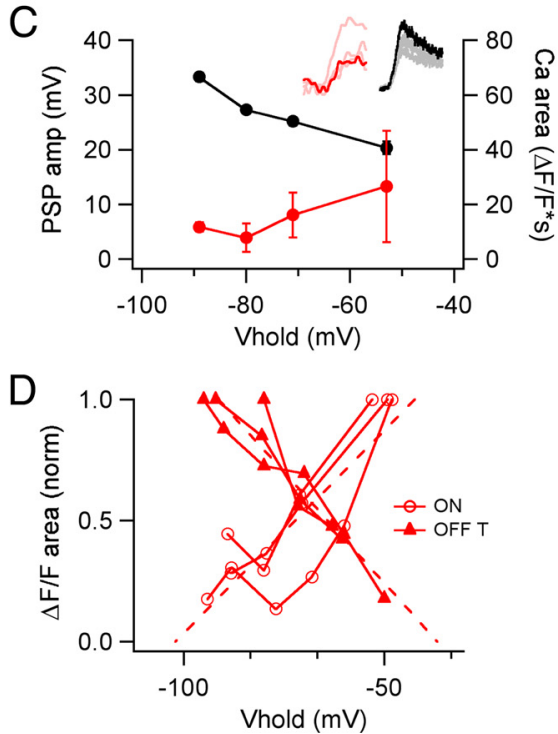

OFF T
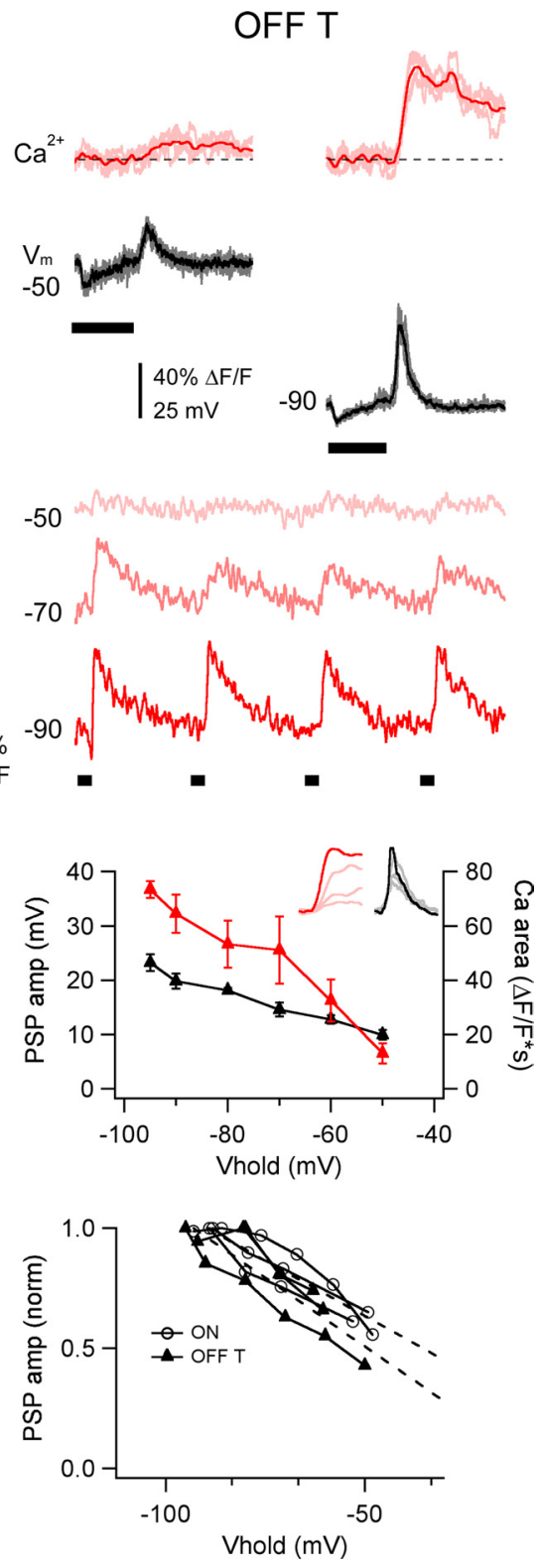

Figure 6. Differential effect of hyperpolarization on light-evoked $\mathrm{Ca}^{2+}$ signals in ON and OFF RGCs. A, Simultaneously measured proximal dendritic $\mathrm{Ca}^{2+}$ signals ( $\mathrm{Ca}^{2+}$; red) and somatic voltage $\left(V_{\mathrm{m}} ;\right.$ black) in $\mathrm{ON}$ (left) and OFF-T (right) RGCs in response to a $0.5 \mathrm{~s}$ light step (bar under $V_{\mathrm{m}}$ ) near resting potential and during hyperpolarizing current injection. Means superimposed on 4-7 individual sweeps. Recordings in CC mode in the presence of $0.1 \mu \mathrm{M}$ TTX. $B, \mathrm{Ca}^{2+}$ signals from cells in $\boldsymbol{A}$ in response to repeated light stimuli (bars, below) at different somatic membrane potentials (indicated at left in millivolts). Each sweep is $15 \mathrm{~s}$ and light step is $0.5 \mathrm{~s}$. Scale bar at middle applies to left and right. C, PSP amplitude and $\mathrm{Ca}^{2+}$ signal area as a function of somatic holding potential for the same cells, showing dissociation between PSP and $\mathrm{Ca}^{2+}$ signal amplitude in the $\mathrm{ON}$ cell (left), and their correspondence in the $0 \mathrm{FF}$ cell (right). Insets contain response families $\left(\mathrm{Ca}^{2+}\right.$, red; $V_{\mathrm{m}}$, black) where the darker hue represents the most hyperpolarized $V_{\text {hold }}$. Error bars show \pm SD. D, Normalized $\mathrm{Ca}^{2+}$ signal area (left) and PSP amplitude (right) vs $V_{\text {hold }}$ for 6 cells ( 3 ON, 3 OFF-T). Fourteen measurements from $30 \mathrm{~N}$ cells, 13 measurements from 3 OFF-T cells, where each point is an average of 1-10 light-evoked $\mathrm{Ca}^{2+}$ signals (total $65-70$ measurements for each cell type; error bars not shown). Dotted lines are linear fits. Left, Pearson's linear correlation coefficient $+0.84(p=0.0001)$ for the $0 \mathrm{~N} \mathrm{cells} \mathrm{and}-0.95(p<0.000001)$ for OFF-T cells; right, linear slope -0.92 for the $0 \mathrm{~N}$ cells and -0.86 for the OFF-T cells. Recordings made in the presence of $0.1 \mu \mathrm{M} \mathrm{TTX}$.

$V_{\text {hold }}=-70 \mathrm{mV}$ ) or LVA Ca ${ }^{2+}$ entry (return to $-70 \mathrm{mV}$ at the termination of a hyperpolarizing voltage step). Stimulus strengths were adjusted to make the peak amplitudes of the HVA and LVA $\mathrm{Ca}^{2+}$ signals recorded in proximal dendrite equivalent (Fig. 5A). Since the dendrites of OFF RGCs are semiplanar many regions of interest were captured in a single line scan allowing simultaneous measurement $(500 \mathrm{~Hz})$ of dendritic $\mathrm{Ca}^{2+}$ signals from multiple sites; in this case 5 sites, the farthest of which was $\sim 130 \mu \mathrm{m}$ from the soma (Fig. 5A, right). Responses evoked by either the HVA or LVA stimulus decreased as the distance from the soma to the dendritic recording site increased (Fig. 5C). HVA-evoked $\mathrm{Ca}^{2+}$ signals, however, fell off more rapidly with distance than the LVA Ca ${ }^{2+}$ signal (Fig. $5 B$ ). As a result the ratio of the peak amplitudes of the $\mathrm{Ca}^{2+}$ signals evoked by LVA and HVA stimuli increased as the optical recording site was moved away from the soma; in the illustrated case the ratio increased from $\sim 1$ at 22 $\mu \mathrm{m}$ to $\sim 2$ at $132 \mu \mathrm{m}$. On average the LVA: HVA ratio was $1.3 \pm 0.1$ at the proximal dendrite and $2.2 \pm 0.3$ at the distal dendrite, an increase of 1.7-fold (peak: $p=0.001$; area: $p=0.006 ; n=9$ ) (Fig. $5 C$, right).

Consistently larger LVA signals in distal dendrites were also measured in current-clamp recordings (Fig. 5D). The delay between $\mathrm{Ca}^{2+}$ signal onset and spike activity evoked by depolarizing current injection (as in Fig. 1D) was greater at distal than proximal dendritic recording sites, consistent with the initial slope of the rising phase of the $\mathrm{Ca}^{2+}$ response decreasing with distance. In contrast the onset of the $\mathrm{Ca}^{2+}$ signal evoked by rebound excitation (and by LVA stimuli in voltage clamp) appeared to be coincident with the onset of spike activity, and was independent of the location of the dendritic recording site (Fig. $5 B, D$, right).

\section{Light-evoked dendritic $\mathrm{Ca}^{2+}$ signals} In both ON and OFF RGCs, the depolarizing phase of the light response (at light onset for ON cells; light offset for OFF cells) was associated with an increase in dendritic $\mathrm{Ca}^{2+}$ (Fig. 6). These experiments were done in the presence of $0.1 \mu \mathrm{M}$ TTX to isolate the light-evoked $\mathrm{Ca}^{2+}$ signals from those produced by APs. At voltages in the vicinity of the normal resting potential the light-evoked $\mathrm{Ca}^{2+}$ signals in ON and OFF RGCs were on average roughly similar in amplitude and kinetics. Hyperpolarizing either cell type using negative current injection increased their light-evoked depolarizing PSPs but had opposite effects on their $\mathrm{Ca}^{2+}$ responses; hyperpolarization reduced the lightevoked $\mathrm{Ca}^{2+}$ increase in ON RGCs and increased it in OFF cells (Fig. 6A-C). For the representative cells in Figure 6 hyperpolarization decreased the $\mathrm{Ca}^{2+}$ signal by $\sim 75 \%$ in the ON cell $\left(\Delta V_{\mathrm{m}}-53\right.$ to $\left.-80 \mathrm{mV}\right)$ and increased it by $\sim 5$-fold in the OFF-T cell $\left(\Delta V_{\mathrm{m}}-50\right.$ to -90 $\mathrm{mV}$ ), while it increased PSP amplitude in both cell types. This point is further illustrated in Figure $6 D$, which plots the average normalized area of the $\mathrm{Ca}^{2+}$ signals (left) and PSP amplitudes (right) recorded at different holding potentials from $3 \mathrm{ON}$ and 3 OFF-T cells. The slopes of linear fits to the $\mathrm{Ca}^{2+}$ signal data had 

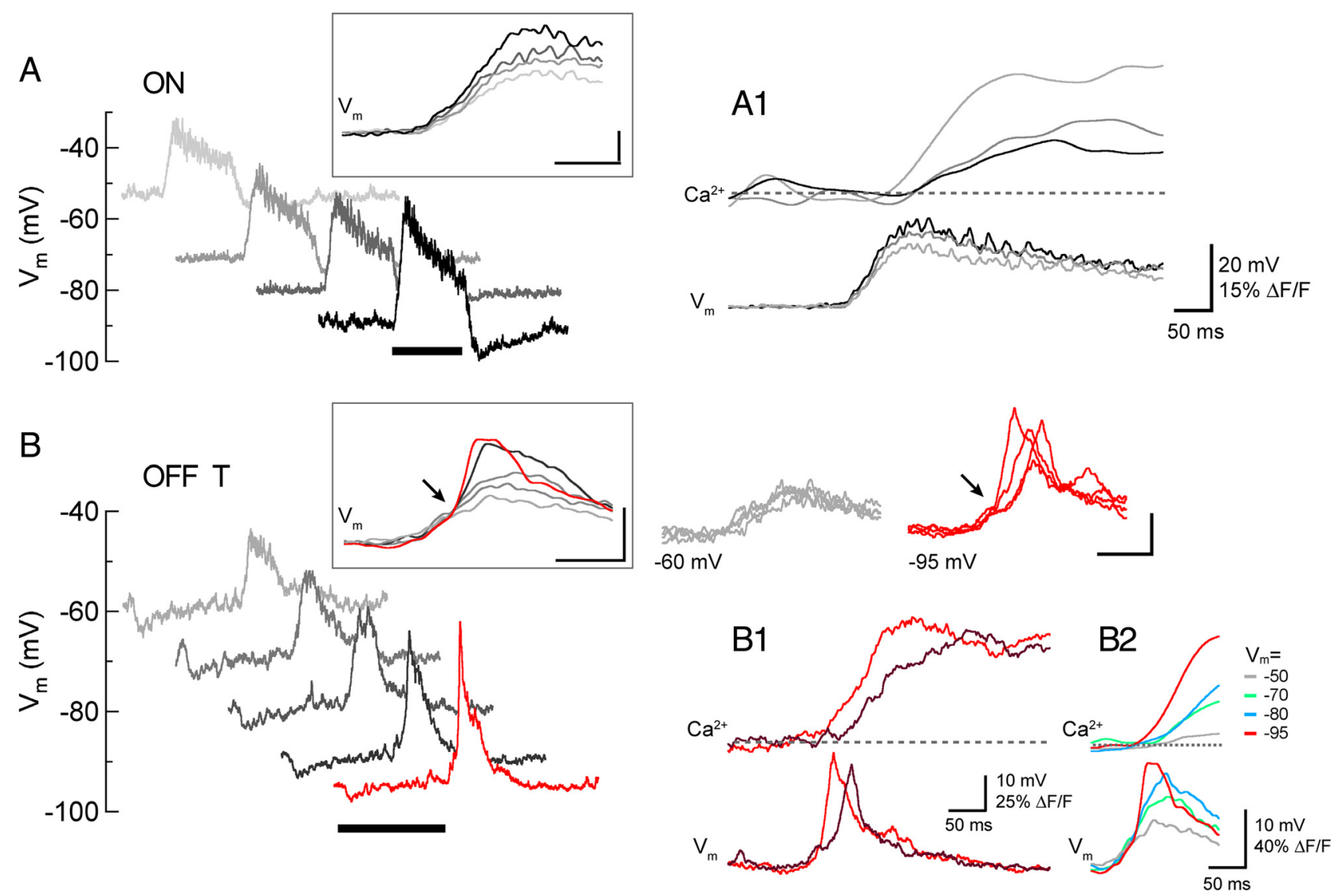

Figure 7. Dynamics of light-evoked $\mathrm{Ca}^{2+}$ signals. $\boldsymbol{A}$, Changes in light-evoked voltage with increasing hyperpolarization in an $0 \mathrm{~N}$ cell. Insets show means of $3-5$ responses at each membrane potential. $\boldsymbol{A 1}$, Mean proximal dendritic $\mathrm{Ca}^{2+}$ signals (same cell as in $\boldsymbol{A}$ ) at 3 different $V_{\mathrm{m}}$ values. Note that delay to $\mathrm{Ca}^{2+}$ signal onset is shortest at the most depolarized $V_{\mathrm{m}}$ (light gray). $\boldsymbol{B}$, Same as $\boldsymbol{A}$ for an OFF-T cell, with the discontinuity in the rising phase indicated by arrow. Superimposed traces at right of $\boldsymbol{B}$ inset are 4 individual sweeps at $V_{\mathrm{m}}=-60$ (gray) and -95 (red). $\boldsymbol{B} 1$, Individual traces from OFF-T cell $\left(V_{\mathrm{m}}=-95 \mathrm{mV}\right)$ showing the close coincidence between the onset of time of depolarizing light response and the dendritic $\mathrm{Ca}^{2+}$ signal. $\mathbf{B 2}$, Mean proximal dendritic $\mathrm{Ca}^{2+}$ signals at 4 different membrane potentials, showing that delay to $\mathrm{Ca}^{2+}$ signal onset is shortest from the most hyperpolarized $V_{\mathrm{m}}(\mathrm{red})$, where the discontinuity in the rising phase of the voltage response is prominent. $V_{\text {rest }}=-60 \mathrm{mV}$. Recordings made in the presence of $0.1 \mu \mathrm{m}$ TTX.

opposite signs in ON and OFF cells (Fig. 6D, left, dotted lines; $p=$ $0.0011)$, while the slopes of the PSP data had the same sign and were not significantly different in the two cell types (Fig. $6 D$, right; $p>0.1$ ). The increase in PSP amplitude with hyperpolarization is consistent with increased driving force on the lightevoked synaptic conductance. The effects of increasing holding potential on the waveform of light-evoked PSPs was different, however, in ON and OFF-T cells (Fig. 7). At holding potentials ranging from -54 to $-90 \mathrm{mV}$, the rising phases of the $\mathrm{ON}$ cell voltage responses increased with a slope of $\sim 250-350 \mathrm{mV} / \mathrm{s}$ and were associated with dendritic $\mathrm{Ca}^{2+}$ signals with smoothly increasing rising phases (Fig. 7A). While the depolarizing light responses in OFF-T cells showed similar voltage dynamics at holding potentials near their resting potential, at more negative voltages the onset of the response included an inflection point at which there was an abrupt increase in the slope of the rising phase (Fig. 7B, arrows). This occurred after a small initial slower depolarization (slope before inflection point: $139 \pm 14 \mathrm{mV} / \mathrm{s}$ ) that appeared to reach a threshold for activating a regenerative component (slope after inflection point: $1020 \pm 221 \mathrm{mV} / \mathrm{s}$ ). The onset of the fast-rising component of the voltage response was associated with an abrupt increase in the amplitude of light-evoked $\mathrm{Ca}^{2+}$ signal. In responses evoked by repeated presentations of the same stimulus, the timing of the voltage inflection point and the onset time of the $\mathrm{Ca}^{2+}$ increase closely covaried (Fig. 7B1). On average, responses with a fast-rising voltage component were as- sociated with the largest and shortest latency $\mathrm{Ca}^{2+}$ increases (Fig. 7 B2). This occurred at voltages negative to $\sim-80 \mathrm{mV}$, corresponding to the voltage for threshold activation of rebound depolarization (Fig. 2) and LVA Ca ${ }^{2+}$ current (Figs. 3, 4).

The results presented suggest that $\mathrm{Ca}^{2+}$ entry via voltagegated $\mathrm{Ca}^{2+}$ channels underlies the generation of light-evoked dendritic $\mathrm{Ca}^{2+}$ signals in both ON and OFF type RGCs. In this scenario, the depolarizing response produced by light driven excitatory synaptic input would activate exclusively $\mathrm{HVA} \mathrm{Ca}^{2+}$ channels in ON cells and in OFF cells a combination of HVA and LVA Ca ${ }^{2+}$ channels that depends on membrane potential. The proposed voltage dependence of the $\mathrm{Ca}^{2+}$ signals was explored further using whole-cell voltage clamp. In these experiments light-evoked $\mathrm{Ca}^{2+}$ signals were optically recorded at a fixed dendritic location and the whole-cell-recording mode was switched from CC to voltage clamp (VC) without changing the light stimulus or $V_{\text {hold }}$. Optical recording sites were restricted to about the proximal third of the dendritic arbor $(10-60 \mu \mathrm{m}$ from the soma) to minimize potential space-clamp errors. The switch from CC to VC provides a way to test whether light-evoked $\mathrm{Ca}^{2+}$ signals are produced by voltage-gated $\mathrm{Ca}^{2+}$ channels, in which case they would be attenuated by VC, or are the result of synaptic activation of $\mathrm{Ca}^{2+}$-permeable AMPA receptors, which would give rise to $\mathrm{Ca}^{2+}$ signals that are not affected by clamping membrane voltage. Such an experiment is shown in Figure 8 for representative examples of ON (Fig. $8 A$ ) and OFF-T (Fig. $8 B$ ) cell types. In 

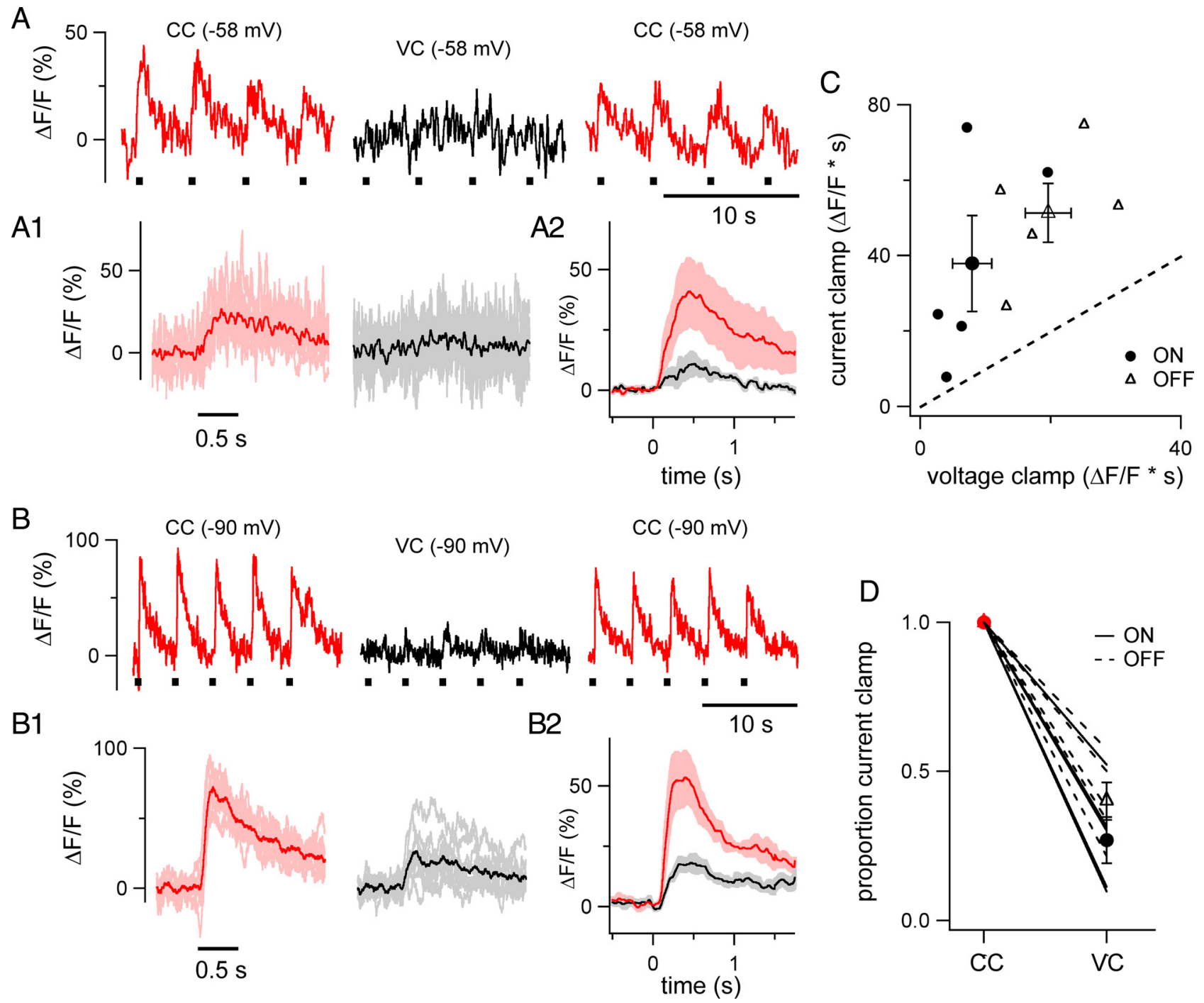

Figure 8. Reduction of light-evoked $\mathrm{Ca}^{2+}$ signals by voltage clamp. $A$, Proximal dendritic $\mathrm{Ca}^{2+}$ signals from an $0 \mathrm{~N} \mathrm{cell} \mathrm{in} \mathrm{response} \mathrm{to} \mathrm{four} \mathrm{consecutive} \mathrm{flashes} \mathrm{of} \mathrm{lightin} C\left(\mathrm{Crecording}\right.$ (left, $V_{\text {rest }}=-58 \mathrm{mV}$ ), VC recording (middle, $V_{\text {hold }}=-58 \mathrm{mV}$ ), and again in CC mode after switching from VC (right, $V_{\text {rest }}=-58 \mathrm{mV}$ ). Light flashes $(0.5 \mathrm{~s})$ shown by black bars below sweeps. A1, Mean (darker trace) light-evoked $\mathrm{Ca}^{2+}$ signal of 10 responses from the cell in $\boldsymbol{A}(\mathrm{CC}$, red; $\mathrm{VC}$ black). Aligned to the onset of the light stimulus. Response peak reduced by $73 \%$; area reduced by $52 \%$. $\boldsymbol{A 2}$, Average light-evoked $\mathrm{Ca}^{2+}$ signal in $50 \mathrm{~N}$ cells (CC, red; VC, black). Pink and gray show \pm SEM. B, Proximal dendritic $\mathrm{Ca}^{2+}$ signals from an OFF-T cell in response to five consecutive flashes of light in CC mode (left, $V_{\text {hold }}=-90 \mathrm{mV}$ ), VC mode (middle, $V_{\text {hold }}=-90 \mathrm{mV}$ ), and again in CC mode after switching from VC (right $V_{\text {rest }}=-90 \mathrm{mV}$ ). Light flashes $(0.5 \mathrm{~s}$ ) shown by black bars below sweeps. $B 1$, Mean (darker trace) light-evoked $\mathrm{Ca}^{2+}$ signal of 10 responses from the cell in $\boldsymbol{B}(\mathrm{CC}$, red; $\mathrm{VC}$, black). Aligned to offset of light stimulus. Response peak and area reduced by $63 \%$. B2, Average light-evoked $\mathrm{Ca}^{2+}$ signal in 5 OFF-T cells (CC, red; VC, black). Pink and gray show \pm SEM. C, Area ( $\triangle F / F^{*}$ s) of light-evoked $\mathrm{Ca}^{2+}$ signals recorded in current clamp versus voltage clamp. Each small symbol represents the mean of $8-44$ sweeps from an individual cell (pooled over $V_{\text {hold }}$ values between -90 and $-60 \mathrm{mV}$ and $2-3$ optical recording sites) from $50 \mathrm{~N}$ cells (black circles) and $50 \mathrm{FF}-\mathrm{T}$ cells (open triangles) in which both CC and VC responses were recorded. Large symbols show mean ( \pm SEM) for each group. Dotted line is unity. D, Proportional reduction of $\mathrm{Ca}^{2+}{ }^{2+}$ signals in VC mode. Lines connect measurements from individual cells ( 5 ON, solid lines; 5 OFF-T, dotted lines). Symbols show group means \pm SEM. Recordings made in the presence of $0.1 \mu \mathrm{M}$ TTX.

current-clamp recordings in the presence of $0.1 \mu \mathrm{M}$ TTX the cells were held at potentials that produced large $\mathrm{Ca}^{2+}$ signals, i.e., -58 $\mathrm{mV}$ for the ON cell and $-90 \mathrm{mV}$ for the OFF-T cells (Fig. 8A,B). Clamping the voltage of the $\mathrm{ON}$ and OFF cells at the same holding potentials used in current clamp reduced their light-evoked $\mathrm{Ca}^{2+}$ signals (Fig. 8A1,B1). The switch from current to voltage clamp decreased the area and peak of the $\mathrm{Ca}^{2+}$ responses by $\sim 60 \%$ in both of the two cell types. The effect of switching from CC to VC was readily reversible upon switching back to CC (Fig. 8A,B). Mean responses collected from $5 \mathrm{ON}$ and 5 OFF-T cells are shown in Figure 8, A2 and B2. Holding the membrane potential at a fixed level under voltage-clamp conditions reduced $\mathrm{Ca}^{2+}$ signals in all recordings. This is shown in Figure $8 C$, which plots the area of the $\mathrm{Ca}^{2+}$ signal $\left(\Delta F / F^{*} \mathrm{~s}\right)$ in $\mathrm{CC}$ versus $\mathrm{VC}$ recording mode. Every point, which represents the mean of $8-44$ total responses from an individual cell, falls above unity, indicating that light-evoked $\mathrm{Ca}^{2+}$ responses were larger under CC than VC ( $p=0.0008,10$ cells). While the dependence of voltage-clamped $\mathrm{Ca}^{2+}$ signals on $V_{\text {hold }}$ was not systematically investigated, data in Figure $8 C$ include experiments across a range of $V_{\text {hold }}$ values $(-95$ to $-53 \mathrm{mV})$ and on average (Fig. $8 D)$ the switch from CC to $\mathrm{VC}$ reduced the light-evoked $\mathrm{Ca}^{2+}$ signal by $73.1 \pm 7.8 \%$ in ON cells and $59.9 \pm 6.3 \%$ in OFF-T cells $(n=5$ ON and 5 OFF-T cells; $p=0.23$ ).

\section{Discussion}

Intracellular $\mathrm{Ca}^{2+}$ signals are generated in retinal ganglion cell dendrites in response to both electrode-elicited voltage changes and visual stimulation. Voltage-dependent $\mathrm{Ca}^{2+}$ influx is mediated by two types of voltage-gated $\mathrm{Ca}^{2+}$ channels; high-voltage 
and low-voltage activated $\mathrm{Ca}^{2+}$ channels, HVA and LVA respectively. This is consistent with previous electrophysiological studies that recorded HVA and LVA Ca ${ }^{2+}$ currents in isolated retinal neurons from dissociated mammalian (Lipton and Tauck, 1987; Karschin and Lipton, 1989; Guenther et al., 1994) and lower vertebrate (Lee et al., 2003; Mitra and Miller, 2007) retina. The present study combines somatic electrical recording and dendritic 2-photon $\mathrm{Ca}^{2+}$ imaging and focuses on two major subclasses of retinal output neurons, ON and OFF $\alpha$ RGCs. The results show that $\mathrm{HVACa}^{2+}$ channels are present in both $\mathrm{ON}$ and OFF RGCs, while LVA Ca ${ }^{2+}$ channels are present in only OFF RGCs. The differences in $\mathrm{Ca}^{2+}$ channel expression in these two cell types complements previously described functional asymmetries in ON and OFF synaptic pathways (Chichilnisky and Kalmar, 2002; Zaghloul et al., 2003; Sagdullaev et al., 2006). The differential expression of the LVA Ca ${ }^{2+}$ channels is also in agreement with an earlier study that recorded LVA $\mathrm{Ca}^{2+}$ currents in only a subset ( $\sim 30 \%$ ) of unidentified isolated rat RGCs (Guenther et al., 1994). While our study found clear differences between ON, OFF-T and OFF-S $\alpha$ RGCs, these are only three of more than a dozen morphologically distinct kinds of mouse ganglion cells (Sun et al., 2002; Badea and Nathans, 2004; Kong et al., 2005), leaving open questions about the expression of dendritic $\mathrm{Ca}^{2+}$ channels in general and $\mathrm{LVA} \mathrm{Ca}^{2+}$ channels in particular in other types of RGCs.

\section{Functional implications of HVA and LVA signaling}

Near the resting potential $(\sim 60 \mathrm{mV}) \mathrm{HVA} \mathrm{Ca}^{2+}$ channels in both ON and OFF type RGCs are closed and the threshold voltage for triggering HVA Ca ${ }^{2+}$ entry is slightly more positive (Fig. 4). The preponderance of $\mathrm{LVA} \mathrm{Ca}^{2+}$ channels in OFF cells is also closed at voltages in the vicinity of the resting potential but unlike the case for HVA channels, the LVA channels are closed due to inactivation. Voltage-evoked $\mathrm{Ca}^{2+}$ entry via LVA channels requires that they first be brought out of inactivation by hyperpolarization. The threshold voltage for triggering $\mathrm{Ca}^{2+}$ entry through LVA $\mathrm{Ca}^{2+}$ channels deinactivated by a negative $(-90 \mathrm{mV})$ holding potential is $\sim-80 \mathrm{mV}$ (Fig. 4). The depolarization that occurs at the end of a hyperpolarizing current step opens LVA channels producing an inward $\mathrm{Ca}^{2+}$ current that triggers a low threshold dendritic $\mathrm{Ca}^{2+}$ spike and a burst of fast large amplitude TTX-sensitive $\mathrm{Na}^{+}$action potentials (Fig. 2). LVA Ca ${ }^{2+}$ channels play the same role in triggering rebound excitation in a variety of neuronal cell types (Llinás, 1988; Huguenard, 1996).

Our results suggest that the LVA $\mathrm{Ca}^{2+}$ channels initiate rebound excitation in OFF RGCs to generate a precisely timed OFF response at the termination of a step of light (Fig. 7). OFF cells receive strong inhibitory synaptic input. The ratio of inhibition to excitation is approximately 5 times larger for OFF cells than ON cells (Pang et al., 2003; Murphy and Rieke, 2006). This supports the idea that $\mathrm{LVA} \mathrm{Ca}^{2+}$ channels are deinactivated during the hyperpolarizing synaptic potential and are in turn activated at light offset when the cell depolarizes due to the termination of synaptic inhibition and the arrival of excitatory synaptic input from OFF bipolar cells. The rebound-activated inward $\mathrm{Ca}^{2+}$ current interacts with the excitatory synaptic current to generate an abrupt depolarizing potential change that triggers a brief burst of spikes. It should be noted that light adaptation could modulate the role of LVA channels in OFF ganglion cell firing if the balance of excitatory and inhibitory input is shifted (Manookin et al., 2008).

Activation of LVA channels in OFF RGCs provides a mechanism that couples light offset to a precisely timed burst of spikes. Without LVA channels, the membrane potential change at light offset would reflect the summed effect of a decrease in strong inhibitory input and an increase in weak excitatory synaptic input (Murphy and Rieke, 2006). It would be temporally imprecise, and have a low safety factor for spike generation. Moreover, the presence of LVA channels in distal dendrites endows the OFF cell with the means to convert the termination of what is predominantly an inhibitory local synaptic potential into a robust excitatory signal that reaches the soma as a propagated dendritic spike. ON RGCs do not need such a mechanism to signal the onset of light, which is triggered by direct excitatory synaptic input from ON bipolar cells without strong preceding inhibition.

\section{Spatial distribution of HVA and LVA $\mathrm{Ca}^{2+}$ signaling}

The mechanism proposed above for the generation of a precisely time OFF response in OFF RGCs requires that light-evoked IPSPs in OFF cells are large enough to deinactivate a significant number of LVA $\mathrm{Ca}^{2+}$ channels in order for them to be activated at the termination of the light stimulus. While the minimum membrane potential required for deinactivation of a substantial fraction of $\mathrm{LVA} \mathrm{Ca}^{2+}$ channels is $\sim-80 \mathrm{mV}$ (Fig. $2 \mathrm{D}$ ), light-evoked IPSPs in OFF cells appear to fall far short of reaching potentials as negative as this (Figs. 6A, 7B). In considering this apparent mismatch, it is important to recognize that the voltage measurements were based on somatic recording (voltages were imposed and recorded at the soma) while the $\mathrm{Ca}^{2+}$ signals were measured in the dendrite. A hyperpolarizing voltage step applied to the soma is attenuated as it spreads out the dendrite. Similarly, a hyperpolarizing voltage change imposed on the dendrite by a local IPSP is attenuated as it spreads from the dendrite to the soma. The IPSP is larger in the dendrite than the soma not only because of decrement along the dendritic cable but also because the increased input resistance in small diameter dendrites increases the amplitude of the voltage change produced by local synaptic input current (Spruston et al., 2008). This makes a hyperpolarizing voltage change measured in the soma an overestimate of the hyperpolarization needed to deinactivate $\mathrm{LVA} \mathrm{Ca}^{2+}$ channels in distal dendrites and an underestimate of the local IPSP amplitude in the dendrite where the $\mathrm{Ca}^{2+}$ signal is generated and optically recorded. Thus the apparent mismatch between the hyperpolarization needed for LVA channel deinactivation and the amplitude of the light-evoked hyperpolarizing synaptic potential may be attributed to a combination of somatic recording errors in the estimation of the LVA activation voltage and the amplitude of the IPSP in the dendrite. This makes it reasonable to suggest that light-evoked IPSPs locally hyperpolarize dendrites from the cell's normal resting potential to an extent that is sufficient for deinactivation of LVA channels (Fig. 7B). Data from studies using perforated patch or sharp electrode recording (Zaghloul et al., 2003; Murphy and Rieke, 2006) also suggest that OFF $\alpha$ RGCs are hyperpolarized enough by inhibitory input to allow LVA Ca ${ }^{2+}$ channels to participate in rebound excitation.

The voltage-clamp results in Figure 5 show that the HVA $\mathrm{Ca}^{2+}$ signal declines more steeply with dendritic distance from the soma than the LVA signal. There are at least two possible explanations for this. The result could indicate that the LVA signal is more robust in the distal dendrite than is the HVA signal, perhaps due to an increase in the density of LVA relative to HVA $\mathrm{Ca}^{2+}$ channels. Alternatively, it is also possible that the distribution of HVA and LVA channels is uniform along the dendrite but the different stimuli used to evoke the HVA and LVA signals are not affected equally as they travel out the dendrite. The properties of the dendrite might attenuate or amplify one type of stimulus more than the other causing the relative amplitudes of the HVA 
and LVA $\mathrm{Ca}^{2+}$ signals they evoke to be different at proximal and distal recording sites.

Since current-clamp recordings are fundamentally immune to space clamp error, the results in Figure $5 D$, showing that under current-clamp conditions the HVA $\mathrm{Ca}^{2+}$ signal in the distal dendrite is smaller than the LVA signal support the conclusion that the LVA signal is more robust that the HVA signal in the distal dendrite (in agreement with the results obtained under voltage clamp). While the membrane voltage change produced by depolarizing current injection (the HVA stimulus) might spread through the dendritic tree differently than the voltage change produced by the termination of a hyperpolarizing current step (the LVA stimulus), once the cell depolarizes and fires action potentials these differences are no longer relevant. Spikes produced by either stimulus are initiated in the axon/soma and propagate back into the dendrite (Gartland and Detwiler, unpublished observation) where presumably they are affected similarly by the passive and active electrical properties of the dendrite. While it is reasonable to expect that a spike is a spike independent of how it is evoked, without direct evidence that the action potentials that invade the distal dendrites have no memory of whether they were trigger by a HVA or LVA stimulus, it is not possible to reach an unequivocal conclusion about the mechanism responsible for the change in the relative strength of the HVA and LVA Ca ${ }^{2+}$ signals with increasing dendritic distance. We can conclude, however, that regardless of the underlying explanation, from a functional point of view the distal dendrites of OFF RGCs generate stronger LVA than $\mathrm{HVA} \mathrm{Ca}^{2+}$ signals. While this observation may suggest that there are spatial changes in the dendritic density of LVA and HVA $\mathrm{Ca}^{2+}$ channels this remains an open question that needs to be addressed using other approaches, for example, immunocytochemistry.

\section{Light-evoked $\mathrm{Ca}^{2+}$ signals}

Thus far we have dealt mainly with the electrical signals that are produced by inward currents associated with the gating of LVA and $\mathrm{HVA} \mathrm{Ca}{ }^{2+}$ channels and the role they may play in the way ON and OFF RGCs respond to visual stimuli. The activation of either HVA or LVA channels also increases $\mathrm{Ca}^{2+}$ entry to produce a chemical signal carried by a rise in intracellular calcium. The function of this signal is not known.

In the dendrites of central neurons $\mathrm{Ca}^{2+}$ signaling is typically associated with changes in synaptic strength (Malenka, 1991). RGCs in the adult mouse retina show little if any evidence of plasticity (but see Xia et al., 2007). Both ON and OFF RGCs maintain their characteristic dendritic stratification, intrinsic firing properties, including rebound firing in OFF cells, balance of synaptic excitation and inhibition, and dendritic $\mathrm{Ca}^{2+}$ signaling despite being blinded for months by degeneration-induced loss of retinal photoreceptors (Margolis et al., 2008). This suggests that there is a prominent difference between the role $\mathrm{Ca}^{2+}$ signals play in RGCs versus the role they play in most other neurons where changes in intracellular $\mathrm{Ca}^{2+}$ can result in compensatory changes in synaptic function and structure within a matter of hours (Maletic-Savatic et al., 1999).

It is possible that transient light-evoked changes in $\mathrm{Ca}^{2+}$ provide a signal that participates in the maintenance of metabolic homeostasis (Nguyen and Jafri, 2005). It is also possible that $\mathrm{Ca}^{2+}$ signals in RGC dendrites act on $\mathrm{Ca}^{2+}$-dependent conductances to modulate synaptic currents (Akopian and Witkovsky, 2001) or reset the dendrite following light-stimulation, the way discharging a capacitor may reset an integrator.

Which ion channels generate light-evoked $\mathrm{Ca}^{2+}$ signals? Our results suggest that the rise in intracellular $\mathrm{Ca}^{2+}$ is primarily due to entry through voltage-gated $\mathrm{Ca}^{2+}$ channels rather than through $\mathrm{Ca}^{2+}$-permeable ligand-gated glutamate receptors, i.e., $\mathrm{Ca}^{2+}$-permeable AMPA receptors (Ca-AMPARs) and NMDA receptors (NMDARs). Under the conditions of these experiments light-evoked $\mathrm{Ca}^{2+}$ signals in both cell types are voltage dependent as shown by the marked reduction in the amplitude of $\mathrm{Ca}^{2+}$ signals upon switching from current- to voltage-clamp recording at fixed holding potential (Fig. 8). This would not be expected to affect the amplitude of $\mathrm{Ca}^{2+}$ increases that were predominantly mediated by Ca-AMPARs and/or NMDARs. Nonetheless, our results do not exclude the possibility that NMDARs participate in the generation of $\mathrm{Ca}^{2+}$ signals at voltages that relieve $\mathrm{Mg}^{2+}$ block (Mittman et al., 1990; Hille, 2001).

\section{References}

Aizenman CD, Linden DJ (1999) Regulation of the rebound depolarization and spontaneous firing patterns of deep nuclear neurons in slices of rat cerebellum. J Neurophysiol 82:1697-1709.

Akopian A, Witkovsky P (2001) Intracellular calcium reduces light-induced excitatory post-synaptic responses in salamander retinal ganglion cells. J Physiol 532:43-53.

Awatramani GB, Slaughter MM (2000) Origin of transient and sustained responses in ganglion cells of the retina. J Neurosci 20:7087-7095.

Badea TC, Nathans J (2004) Quantitative analysis of neuronal morphologies in the mouse retina visualized by using a genetically directed reporter. J Comp Neurol 480:331-351.

Chichilnisky EJ, Kalmar RS (2002) Functional asymmetries in ON and OFF ganglion cells of primate retina. J Neurosci 22:2737-2747.

Crunelli V, Lightowler S, Pollard CE (1989) A T-type $\mathrm{Ca}^{2+}$ current underlies low-threshold $\mathrm{Ca}^{2+}$ potentials in cells of the cat and rat lateral geniculate nucleus. J Physiol 413:543-561.

Denk W, Strickler JH, Webb WW (1990) Two-photon laser scanning fluorescence microscopy. Science 248:73-76.

Euler T, Hausselt SE, Margolis DJ, Breuninger T, Castell X, Detwiler PB, Denk W (2009) Eyecup scope-optical recordings of light stimulus-evoked fluorescence signals in the retina. Pflugers Arch 457:1393-1414.

Guenther E, Rothe T, Taschenberger H, Grantyn R (1994) Separation of calcium currents in retinal ganglion cells from postnatal rat. Brain Res 633:223-235.

Hille B (2001) Ion channels of excitable membranes, Ed 3. Sunderland, MA: Sinauer.

Huguenard JR (1996) Low-threshold calcium currents in central nervous system neurons. Annu Rev Physiol 58:329-348.

Karschin A, Lipton SA (1989) Calcium channels in solitary retinal ganglion cells from post-natal rat. J Physiol 418:379-396.

Kong JH, Fish DR, Rockhill RL, Masland RH (2005) Diversity of ganglion cells in the mouse retina: unsupervised morphological classification and its limits. J Comp Neurol 489:293-310.

Lee SC, Hayashida Y, Ishida AT (2003) Availability of low-threshold $\mathrm{Ca}^{2+}$ current in retinal ganglion cells. J Neurophysiol 90:3888-3901.

Lipton SA, Tauck DL (1987) Voltage-dependent conductances of solitary ganglion cells dissociated from the rat retina. J Physiol 385:361-391.

Llinás R, Mühlethaler M (1988) Electrophysiology of guinea-pig cerebellar nuclear cells in the in vitro brain stem-cerebellar preparation. J Physiol 404:241-258.

Llinás RR (1988) The intrinsic electrophysiological properties of mammalian neurons: insights into central nervous system function. Science 242:1654-1664.

Malenka RC (1991) The role of postsynaptic calcium in the induction of long-term potentiation. Mol Neurobiol 5:289-295.

Maletic-Savatic M, Malinow R, Svoboda K (1999) Rapid dendritic morphogenesis in CA1 hippocampal dendrites induced by synaptic activity. Science 283:1923-1927.

Manookin MB, Beaudoin DL, Ernst ZR, Flagel LJ, Demb JB (2008) Disinhibition combines with excitation to extend the operating range of the OFF visual pathway in daylight. J Neurosci 28:4136-4150.

Margolis DJ, Detwiler PB (2007) Different mechanisms generate maintained activity in $\mathrm{ON}$ and OFF retinal ganglion cells. J Neurosci 27:5994-6005.

Margolis DJ, Newkirk G, Euler T, Detwiler PB (2008) Functional stability of 
retinal ganglion cells after degeneration-induced changes in synaptic input. J Neurosci 28:6526-6536.

Mitra P, Miller RF (2007) Mechanism underlying rebound excitation in retinal ganglion cells. Vis Neurosci 24:709-731.

Mittman S, Taylor WR, Copenhagen DR (1990) Concomitant activation of two types of glutamate receptor mediates excitation of salamander retinal ganglion cells. J Physiol 428:175-197.

Molineux ML, McRory JE, McKay BE, Hamid J, Mehaffey WH, Rehak R, Snutch TP, Zamponi GW, Turner RW (2006) Specific T-type calcium channel isoforms are associated with distinct burst phenotypes in deep cerebellar nuclear neurons. Proc Natl Acad Sci U S A 103:5555-5560.

Murphy GJ, Rieke F (2006) Network variability limits stimulus-evoked spike timing precision in retinal ganglion cells. Neuron 52:511-524.

Nelson R, Kolb H (2004) ON and OFF pathways in the vertebrate retina and visual system. In: The visual neurosciences (Chalupa LM, Werner JS, eds), pp 260-278. Cambridge, MA: MIT.

Nguyen MH, Jafri MS (2005) Mitochondrial calcium signaling and energy metabolism. Ann N Y Acad Sci 1047:127-137.

Pang JJ, Gao F, Wu SM (2003) Light-evoked excitatory and inhibitory synaptic inputs to ON and OFF alpha ganglion cells in the mouse retina. J Neurosci 23:6063-6073.

Peichl L (1991) Alpha ganglion cells in mammalian retinae: common properties, species differences, and some comments on other ganglion cells. Vis Neurosci 7:155-169.
Roska B, Molnar A, Werblin FS (2006) Parallel processing in retinal ganglion cells: how integration of space-time patterns of excitation and inhibition form the spiking output. J Neurophysiol 95:3810-3822.

Sagdullaev BT, McCall MA, Lukasiewicz PD (2006) Presynaptic inhibition modulates spillover, creating distinct dynamic response ranges of sensory output. Neuron 50:923-935.

Spruston N, Stuart G, Hausser M (2008) Dendritic integration. In: Dendrites, Chap 14, Ed 2 (Stuart G, Spruston N, Hausser M, eds), pp 351-399. London: Oxford UP.

Sun W, LiN, HeS (2002) Large-scale morphological survey of mouse retinal ganglion cells. J Comp Neurol 451:115-126.

van Wyk M, Wässle H, Taylor WR (2009) Receptive field properties of ONand OFF-ganglion cells in the mouse retina. Vis Neurosci 26:297-308.

Werblin FS, Dowling JE (1969) Organization of the retina of the mudpuppy, Necturus maculosus. II. Intracellular recording. J Neurophysiol 32:339-355.

Xia Y, Nawy S, Carroll RC (2007) Activity-dependent synaptic plasticity in retinal ganglion cells. J Neurosci 27:12221-12229.

Yasuda R, Nimchinsky EA, Scheuss V, Pologruto TA, Oertner TG, Sabatini $\mathrm{BL}$, Svoboda K (2004) Imaging calcium concentration dynamics in small neuronal compartments. Sci STKE 2004:p15.

Zaghloul KA, Boahen K, Demb JB (2003) Different circuits for ON and OFF retinal ganglion cells cause different contrast sensitivities. J Neurosci 23: 2645-2654. 